\title{
19. MAGMATIC EVOLUTION OF THE NORTH AOBA INTRA-ARC BASIN: SITES 832 AND $833^{1}$
}

\author{
T. Hasenaka, ${ }^{2}$ A.J. Crawford,${ }^{3}$ L. Briqueu, ${ }^{4}$ M. Coltorti, ${ }^{5}$ P.E. Baker, ${ }^{6}$ and A. Fujinawa ${ }^{7}$
}

\begin{abstract}
New petrographic and compositional data were reported for 143 samples of core recovered from Sites 832 and 833 during Ocean Drilling Program (ODP) Leg 134. Site 832 is located in the center and Site 833 is on the eastern edge of the North Aoba Basin, in the central part of the New Hebrides Island Arc. This basin is bounded on the east (Espiritu Santo and Malakula islands) and west (Pentecost and Maewo islands) by uplifted volcano-sedimentary ridges associated with collision of the d'Entrecasteaux Zone west of the arc. The currently active Central Belt volcanic front extends through the center of this basin and includes the shield volcanoes of Aoba, Ambrym, and Santa Maria islands.

The oldest rocks recovered by drilling are the lithostratigraphic Unit VII Middle Miocene volcanic breccias in Hole 832B. Lava clasts are basaltic to andesitic, and the dominant phenocryst assemblage is plagioclase + augite + orthopyroxene + olivine . These clasts characteristically contain orthopyroxene, and show a low to medium K calc-alkaline differentiation trend. They are tentatively correlated with poorly documented Miocene calc-alkaline lavas and intrusives on adjacent Espiritu Santo Island, although this correlation demands that the measured $\mathrm{K}-\mathrm{Ar}$ of $5.66 \mathrm{Ma}$ for one clast is too young, due to alteration and Ar loss.

Lava clasts in the Hole 832B Pliocene-Pleistocene sequence are mainly ankaramite or augite-rich basalt and basaltic andesite; two of the most evolved andesites have hornblende phenocrysts. These lavas vary from medium- to high-K compositions and are derived from a spectrum of parental magmas for which their LILE and HFSE contents show a broad inverse correlation with $\mathrm{SiO}_{2}$ contents. We hypothesize that this spectrum results from partial melting of an essentially similar mantle source, with the low-SiO high HFSE melts derived by lower degrees of partial melting probably at higher pressures than the high $\mathrm{SiO}_{2}$, low $\mathrm{HFSE}$ magmas. This same spectrum of compositions occurs on the adjacent Central Chain volcanoes of Aoba and Santa Maria, although the relatively high-HFSE series is known only from Aoba.

Late Pliocene to Pleistocene lava breccias in Hole 833B contain volcanic clasts including ankaramite and augite + olivine + plagioclase-phyric basalt and rare hornblende andesite. These clasts are low-K compositions with flat REE patterns and have geochemical affinities quite different from those recovered from the central part of the basin (Hole 832B). Compositionally very similar lavas occur on Merelava volcano, $80 \mathrm{~km}$ north of Site 833, which sits on the edge of the juvenile Northern (Jean Charcot) Trough backarc basin that has been rifting the northern part of the New Hebrides Island Arc since 2-3 Ma.

The basal sedimentary rocks in Hole 833B are intruded by a series of Middle Pliocene plagioclase + augite \pm olivine-phyric sills with characteristically high- $\mathrm{K}$ evolved basalt to andesite compositions, transitional to shoshonite. These are compositionally correlated with, though $\sim 3 \mathrm{~m}$.y. older than, the high-HFSE series described from Aoba.

The calc-alkaline clasts in Unit VII of Hole 832B, correlated with similar lavas of Espiritu Santo Island further west, presumably were erupted before subduction polarity reversal perhaps 6-10 Ma. All other samples are younger than subduction reversal and were generated above the currently subduction slab. The preponderance in the North Aoba Basin and adjacent Central Chain islands of relatively high-K basaltic samples, some with transitional alkaline compositions, may reflect a response to collision of the d'Entrecasteaux Zone with the arc some 2-4 Ma. This may have modified the thermal structure of the subduction zone, driving magma generation processes to deeper levels than are present normally along the reminder of the New Hebrides Island Arc.
\end{abstract}

\section{INTRODUCTION}

The North Aoba Basin (NAB) forms a part of an intra-arc basin in the central part of the New Hebrides Island Arc. This basin is more than $3000 \mathrm{~m}$ deep and is located between Espiritu Santo Island of the Western Belt and Maewo Island of the Eastern Belt and is bordered by the active Central Chain volcanic islands of Santa Maria (Gaua) in the north and Aoba (Ambae) in the south (Fig. 1). Fisher et al. (1988) correlated the acoustic basement of the basin with early and middle Miocene volcanics presently exposed on Espiritu Santo Island less than $100 \mathrm{~km}$ to the west of Site 832 . Thus the basin fill, with a maximum thickness of $4.9 \mathrm{~km}$ (Holmes, 1988), should preserve a

${ }^{1}$ Greene, H.G., Collot, J.-Y., Stokking, L.B., et al., 1994. Proc. ODP, Sci. Results, 134: College Station, TX (Ocean Drilling Program).

2 Institute of Mineralogy, Petrology, and Economic Geology, Faculty of Science. Tohoku University, Aoba, Sendai, Miyagi 980, Japan.

${ }^{3}$ Department of Geology, University of Tasmania, GPO Box 252C, Hobart, Tasmania 7001, Australia.

${ }^{4}$ Laboratoire de Géochimie Isotopique, URA 1371 du CNRS, Département de Sciences de la Terre, Université Montpellier II, 34095 Montpellier Cedex 05, France.

${ }^{5}$ Instituto de Mineralogia, Universita degli Studi di Ferrara, C.so Ercole $\mathrm{I}^{\circ}$ d'Este, 32 , 44100 , Ferrara, Italy.

${ }^{6}$ Department of Earth Sciences, University of Leeds, Leeds LS2 9JT, UK.

${ }^{7}$ Department of Earth Sciences, Ibaraki University, Bunkyo 2-1-1, Mito 310, Japan. good sedimentary record of post early-Miocene volcanism on nearby islands or submarine volcanic centers.

It is generally accepted that the New Hebrides Island Arc experienced a subduction polarity reversal between Middle and Late Miocene (e.g., Karig and Mammerickx, 1972; Carney and Macfarlane, 1982; Greene et al., 1988). Before opening of the North Fiji Basin (NFB), subduction of the Pacific oceanic plate was from east to west along the presently inactive Vitiaz trench. Since early Late Miocene, the oceanic slab has been underthrusting from west to east during the time that the NFB has been opening (e.g., Auzende et al., 1988). Seismological data are consistent with the existence of the presently steeply east-dipping oceanic slab (Pascal et al., 1978). However, to explain clusters of deep earthquakes beneath the NFB, east of the central part of the New Hebrides Island Arc, Hamburger and Isacks (1987) suggested the continued existence beneath this region of a remanent (detached?) slab of the Pacific Plate that was subducted beneath the Vitiaz arc pre-subduction reversal.

The model for Middle Miocene reversal of subduction polarity beneath this arc system is difficult to prove or disprove from available geochronological and geochemical data for volcanics exposed on the islands. The existence of three volcanic belts (i.e., Western Belt, Central Chain, and Eastern Belt) with somewhat different but overlapping ages make any model for the tectonic development of this arc system rather complicated. 


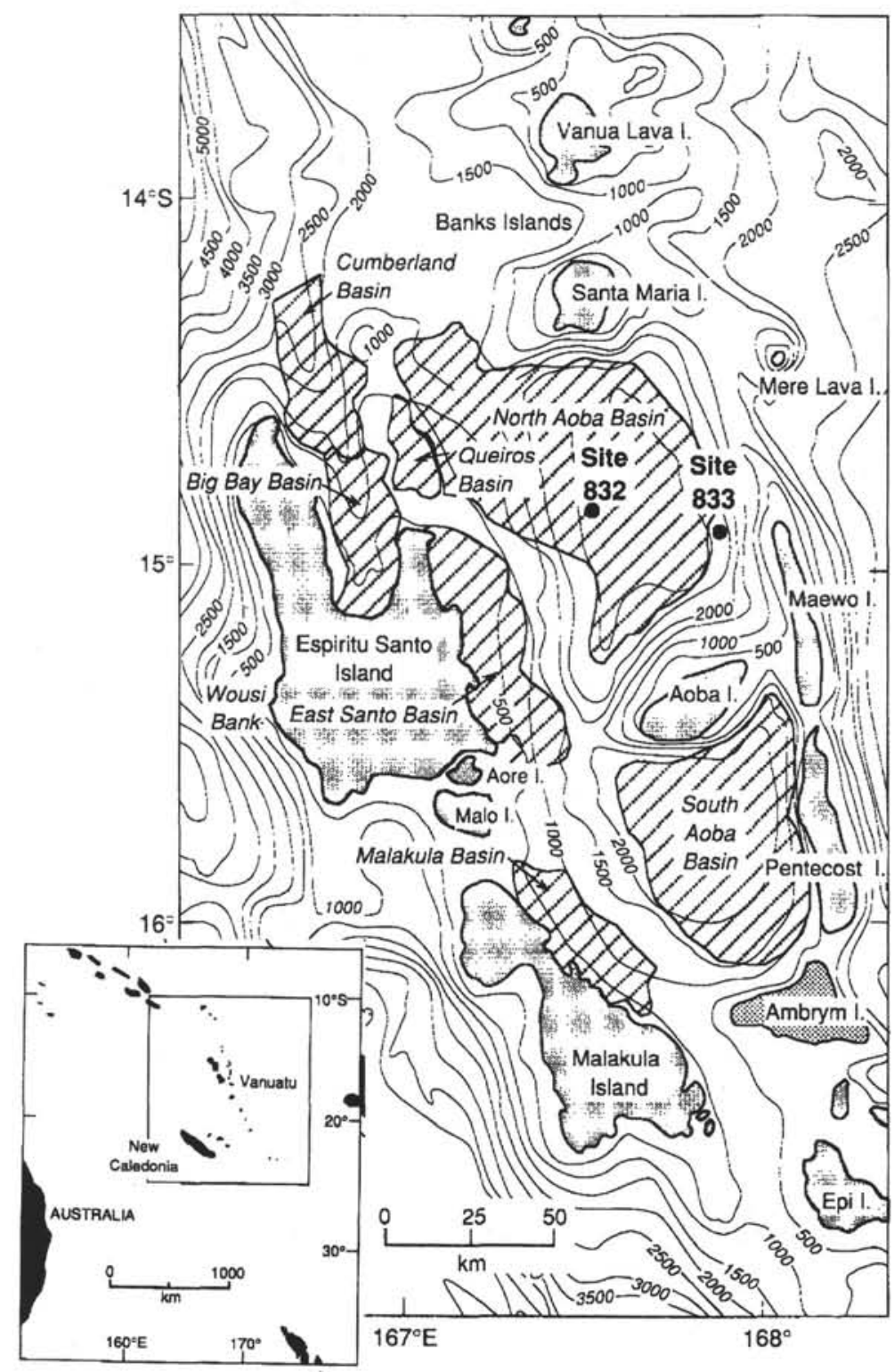

Figure 1. Location of Leg 134 Sites 832 and 833, Vanuatu. The areas with diagonal lines show sedimentary structural basins of the central New Hebrides island arc, Vanuatu. The inset is a locality map of the North Aoba Basin. Figures were taken from Collot, Greene, Stokking, et al. (1992).

A major objective for drilling the two deep holes in the NAB was to recover a full stratigraphic section that would provide a sedimentological and volcanic record of the hypothetical reversal of subduction polarity in this arc system. The principal purpose of this study is to establish the lithostratigraphic and compositional affinities of the volcanic breccias and sills recovered from the NAB during Leg 134, in order to provide information on the changing character of magmatism in the context of this complex intra-arc basin development. Isotopic data for selected samples from Holes $832 \mathrm{~B}$ and $833 \mathrm{~B}$ are reported in Briqueu et al. (this volume). Tephras recovered from the upper levels of the both holes were not included in this study and are described by Baker et al. (this volume) and Gérard and Person (this volume).

\section{GENERAL GEOLOGY AND TECTONIC HISTORY}

The tectonic framework of the New Hebrides Island Arc has been greatly influenced by the opening of the NFB, a marginal (backarc) basin located immediately east of the arc. Before the opening of this basin probably 10-12 Ma (Auzende et al., 1988), a single arc (the Vitiaz arc) existed between the Australia-India and Pacific plates, along the Vitiaz trench. Parts of the New Hebrides Island Arc, the Fiji Islands, and the Lau and Tonga ridges all formed part of this long Vitiaz arc. The late Oligocene to middle Miocene volcanism of the Western Belt of the New Hebrides Island Arc, exposed on the islands of Espiritu Santo and Malakula, is believed to have been produced during this west-dipping subduction. Collision of the Ontong Java Plateau with the northern end of the Vitiaz arc, perhaps around $10 \mathrm{Ma}$, forced a reversal of the subduction polarity and eventual opening of the NFB. The opening of this backarc basin involved clockwise rotation of the New Hebrides Island Arc and counter-clockwise rotation of Fiji (Chase, 1971; Falvey, 1978; Carney and Macfarlane, 1982).

Macfarlane et al. (1988) have summarized the onshore geology of the central New Hebrides Arc. Espiritu Santo Island in the Western Belt developed probably in the late Oligocene to early Miocene, with extensive submarine volcanics between 25 and $15 \mathrm{Ma}$. The oldest rocks include basaltic and andesitic lavas and volcanic breccias, including 
pyroxene- and hornblende-phyric calc-alkaline andesites and basalts. Early to middle Miocene composite and zoned intrusions of basalt, andesite, microdiorite, and minor gabbro are also not uncommon on Espiritu Santo Island. In the middle Miocene (14-11 Ma), volcanogenic graywacke and reef-derived carbonates accumulated in grabens. There is no post middle Miocene magmatism on Espiritu Santo Island, and by late Miocene to early Pliocene time (11-4 Ma) the Western Belt had emerged as a landmass. Final rapid uplift of the Western Belt took place $2-0 \mathrm{Ma}$, in response to the continuing collision and subduction of the d'Entrecasteaux Zone.

The Eastern Belt is an uplifted submarine ridge also produced mainly due to collision of the d'Entrecasteaux Zone. Voluminous basaltic to andesitic submarine volcanism with medium- to high-K affinity took place along the Eastern Belt and later at the eastern edge of the Central Chain (5.8 Ma). Vertical uplift in the early to late Pliocene (4-2 Ma) exposed the Eastern Belt and may have been associated with emplacement of the Basement Complex ophiolites on Pentecost Island. Volcanism on Maewo and Pentecost islands ceased after late Pliocene.

Although volcanism as old as late Miocene is known from the Central Chain islands, it is limited to the northern and southernmost parts of the arc. Most Central Chain volcanism is younger than $3 \mathrm{Ma}$ (Macfarlane et al., 1988).

\section{ANALYTICAL METHODS}

Microprobe analyses were made at University of Leeds using a CAMECA SX-50 instrument fitted with three wavelength dispersive spectrometers and a LINK 10/55S energy dispersive system. Detailed analysis conditions are described in Baker et al. (this volume). XRF analyses were carried out at two different laboratories, Tohoku University, Japan, and University of Ferrara, Italy. Many samples were analyzed at both laboratories, and here we report the Tohoku-analyzed suite, with a few additional samples from the Ferrara-analyzed suite that were not analyzed at Tohoku. The analytical procedures at University of Ferrara are described in Coltorti et al. (this volume). For that at Tohoku University, usually two or three centimeter-sized cubes of volcanic clasts or lavas were first boiled in distilled water until no reaction was detected with the addition of $\mathrm{AgNO}_{3}$ solution. They were then dried and hand-crushed to $\sim$-mm-size grains using an iron mortar and pestle. These coarse powders were then finely crushed using an automatic agate mortar. For major element determinations, glass discs for both standards and samples were made by fusing powders mixed with $\mathrm{LiBO}_{5}$ in the ratio 1:5. Pressed powdered discs for trace element determinations were made from a mixture of rock powder and a small amount of polybynyl alcohol. Both standards and unknown samples were analyzed using a Rigaku 3080 XRF wavelength dispersive spectrometer. The measured X-ray intensities were then corrected for peak overlap, X-ray absorption, and background. The calibration lines (or in some cases curves) obtained for nearly 20 standards, mostly from Geological Survey of Japan, were used to calculate the concentrations.

Rare earth elements (REE) were determined by ICP analysis, with REE solutions being prepared by column separation at Tohoku University, and analyzed using a Jarrel-Ash ICP spectrometer at the Department of Earth Sciences, Ibaraki University. Sample solutions were prepared as follows. One gram of sample powder was digested with a mixed acid $\left(\mathrm{HF}+\mathrm{HClO}_{4}+\mathrm{HNO}_{3}\right)$ in a teflon beaker on a hot plate; REE (La, Ce, Nd, Sm, Eu, Gd, Dy, Er, Yb, and Lu) and Y were separated by a nitric acid cation exchange using DOWEX 50W-X8 resin, followed by a hydrochloric acid anion exchange using DOWEX $1-\mathrm{X} 8.20 \% \mathrm{HCl}$ was added to the final REE separate to make $20 \mathrm{ml}$ of solution for use in single element peak determinations.

\section{LITHOLOGY AND PETROGRAPHY}

At Sites 832 and 833 volcanic rocks are present as clasts in volcanic breccias or sedimentary rocks, or as sills (Fig. 2). 143 samples have been examined petrographically, and according to variations in pheno- cryst assemblages and textures these rocks have been assigned to different lithostratigraphic units.

\section{Site 832}

\section{Lithostratigraphic Unit II (386-462 mbsf)}

This unit is composed of Pleistocene sandstones, siltstones, and claystones, becoming more calcareous in the lower part. Volcanic clasts are found in volcanic sandstone and volcanolithic breccias. Samples for petrographic and geochemical study were taken at three different horizons, 396, 405, and 435 mbsf. These clasts are ankaramite or augite-phyric basalt to basaltic andesite. The typical phenocryst assemblage is augite + plagioclase olivine. Augite (13-35 modal\%) and plagioclase $(10 \%-40 \%)$ phenocrysts predominate, and olivine is subordinate $(0 \%-4 \%)$. Small amounts of opaque oxides are always found. All samples are vesicular, except the andesite. Alteration is relatively minor. Zeolites grow in the vesicles, and palagonite replaces glass.

Sample 134-832B-31R-1, 129-132 cm, (435 mbsf) is a typical basaltic clast with $\sim 10 \%$ vesicles and euhedral to subhedral phenocrysts of augite (35\%, 1-5 mm), serpentine-chlorite pseudomorphs after olivine $(5 \%, 0.3-1.2 \mathrm{~mm})$, plagioclase $(15 \%, 0.3-1.0 \mathrm{~mm})$, and microphenocryst-size Fe-Ti oxide minerals ( $1 \%, 0.1-0.2 \mathrm{~mm}$ ). Groundmass is fine-grained $(<0.05 \mathrm{~mm})$ with plagioclase laths, granular pyroxenes, and $\mathrm{Fe}-\mathrm{Ti}$ oxide minerals, and interstitial spaces are filled by cryptocrystalline minerals and altered, devitrified glass.

\section{Lithostratigraphic Unit III (462-626 mbsf)}

This unit is composed of Pleistocene chalk, limestones, and calcareous mixed sediments with intercalated volcanic siltstones, sandstones, and volcanolithic breccias. Lava clasts in the breccias, mostly 0.2 to $5 \mathrm{~cm}$ long, are supported in a matrix of calcareous siltstones and sandstones. Samples for petrographic and geochemical study were taken at four different horizons: $500,529,552$, and $617 \mathrm{mbsf}$. Although these volcanic breccias were described as basaltic (Collot, Greene, Stokking, et al., 1992), three of the four analyzed are, in fact, basaltic andesites. Two groups of volcanic rocks are found among the volcanic clasts; hornblende andesite, and ankaramite (or augite-phyric basalt). Ankaramite clasts have abundant phenocrysts (up to $48 \%$ augite or $45 \%$ plagioclase), with two containing augite phenocrysts only, and the other two containing both augite and plagioclase. Olivine phenocrysts are not found in any samples, and only trace orthopyroxene has been found in one hornblende andesite. All samples are vesicular, and alteration of glass (up to 15 modal\%) is common.

Sample 134-832B-43R-3, 19-21 cm, representative of the hornblende andesite clasts of this unit, has euhedral to subhedral phenocrysts of plagioclase $(35 \%, 0.3-1.5 \mathrm{~mm})$, augite $(5 \%, 0.3-2.5 \mathrm{~mm})$ and hornblende $(4 \%, 0.3-2.0 \mathrm{~mm})$. Plagioclase phenocrysts have dusty cores full of minute, brown glassy inclusions, and occasional small pyroxene and $\mathrm{Fe}-\mathrm{Ti}$ oxide grains. Hornblende sometimes has reaction rims consisting of aggregates of minute opaque minerals, plagioclase, and pyroxenes. Microphenocryst-sized Fe-Ti oxide minerals $(1 \%, 0.05-0.1 \mathrm{~mm})$ and augite and plagioclase are ubiquitous. Brown glass constitutes most of the groundmass, in which small plagioclase laths, granular pyroxene and $\mathrm{Fe}-\mathrm{Ti}$ oxides are scattered. Irregular-shaped vesicles make up around 5 modal\% of this rock, which is exceptionally fresh and shows no sign of alteration.

\section{Lithostratigraphic Unit IV (626-702 mbsf)}

Basaltic breccia is the main component of this late Pliocene to early Pleistocene unit, which also contains a subordinate amount of volcanic siltstones and sandstones. Basaltic clasts in the breccia are primarily angular to subangular vesicular basalt fragments, ranging in size from sand grains to $20 \mathrm{~cm}$. Clasts are supported in a matrix of sandstone and siltstone. Sample 134-832B-55R-4, 121-125 cm, yielded a K-Ar age of $2.8 \pm 0.8 \mathrm{Ma}$. All analyzed samples from this unit are basaltic. In 


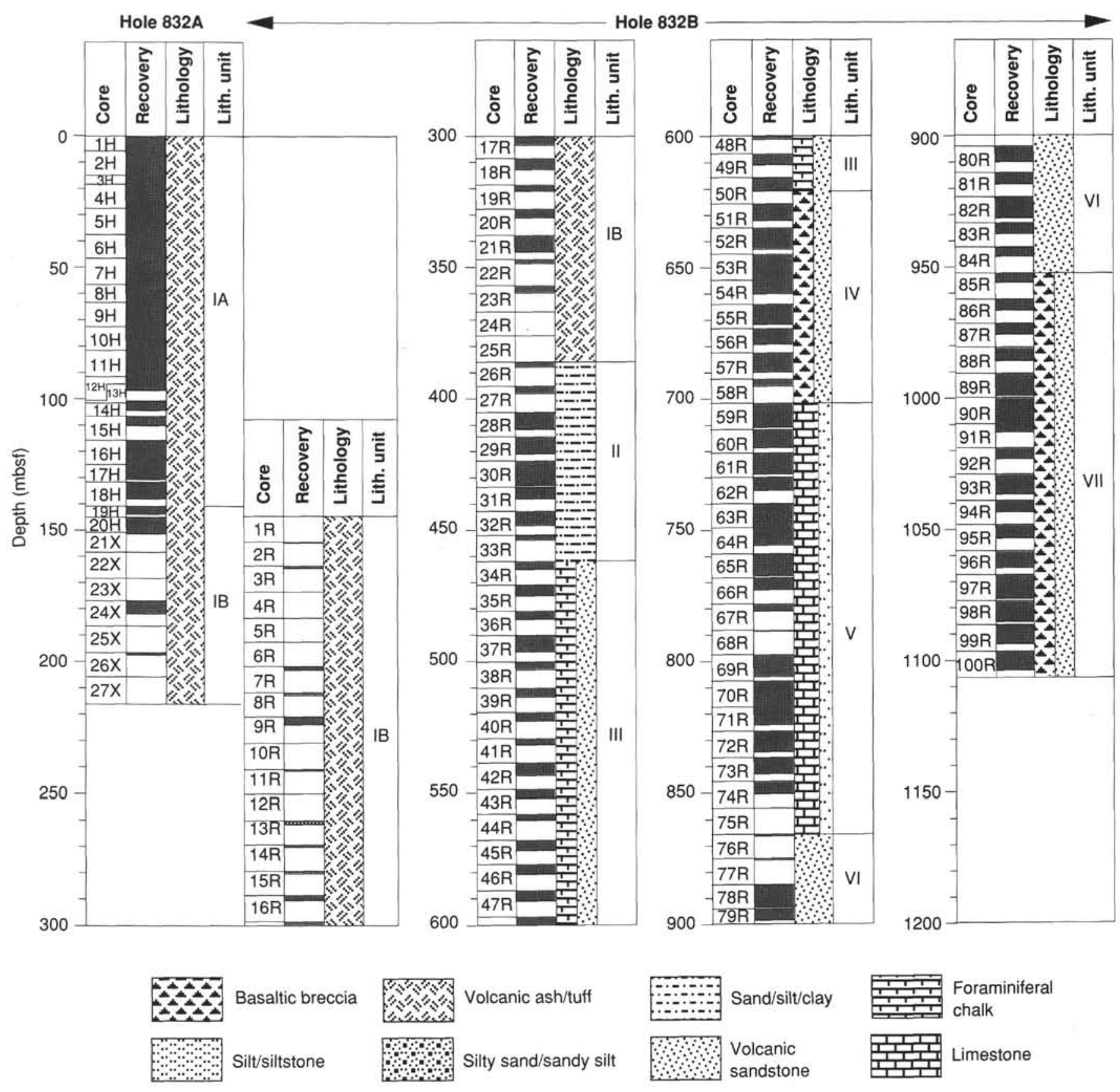

Figure 2. Summary of lithostratigraphic logs from Holes $832 \mathrm{~B}$ and $833 \mathrm{~B}$.

contrast to lithostratigraphic Unit III, in which olivine was absent, most samples taken from this unit contain olivine phenocrysts. Orthopyroxene is found in only one sample. Of 24 samples examined petrographically, 21 have the phenocryst assemblage plagioclase + augite + olivine, two contain only augite phenocrysts, and one contains both augite and orthopyroxene. Fe-Ti oxide minerals are found in most samples. The amount of alteration in some of these clasts is greater than in samples from younger horizons, although all the samples analyzed at Tohoku University are relatively fresh.

Sample 134-832B-56R-2, $46-48 \mathrm{~cm}$, is a typical plagioclase + augite + olivine-phyric basalt of this unit. Euhedral-subhedral phenocrysts include augite $(20 \%, 0.5-3.0 \mathrm{~mm})$, plagioclase $(9 \%, 0.3-1.0$ $\mathrm{mm})$, and olivine $(5 \%, 0.3-1.2 \mathrm{~mm})$. Plagioclase has a dusty appearance partly due alteration along cracks and cleavages, olivine phe- nocrysts show no sign of alteration. The groundmass of most of these lavas have intergranular textures, and zeolites fill the irregular-shaped vesicles which constitute up to 10 modal\% of these rocks. Three other samples have the same phenocryst assemblage, but a partly devitrified glassy matrix altered to palagonite.

\section{Lithostratigraphic Unit V (702-866 mbsf)}

This unit is composed of Late Miocene to Late Pliocene limestone. A basaltic breccia $1.8 \mathrm{~m}$ thick between 836.7 and $838.5 \mathrm{mbsf}$ is the only occurrence of thick breccia in this unit. A single sample taken for petrographic description, at $847 \mathrm{mbsf}$, is plagioclase (33\%) + orthopyroxene (29\%) + augite (3\%)-phyric, and although no chemical analysis is available, it is probably andesitic in composition. 

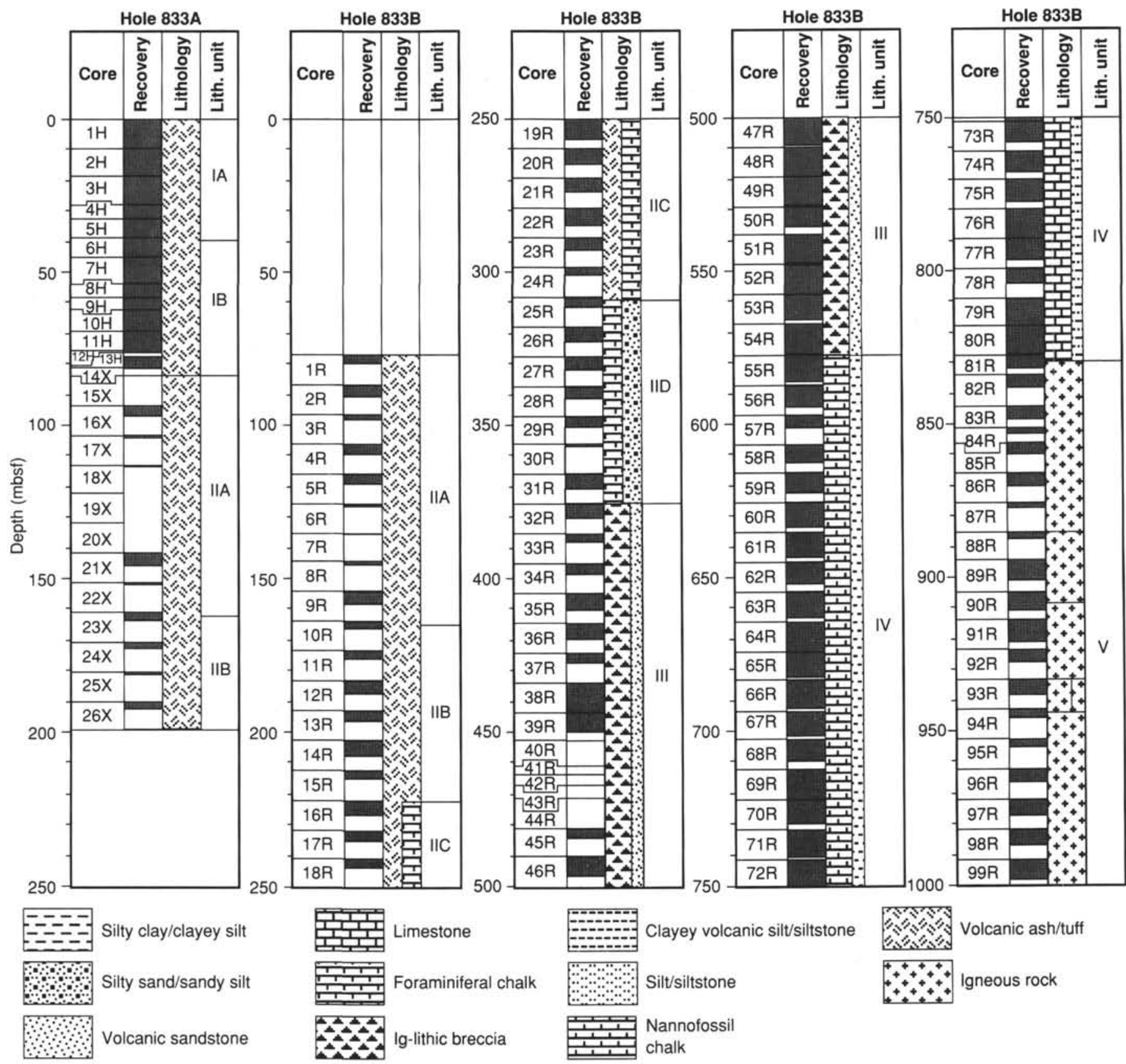

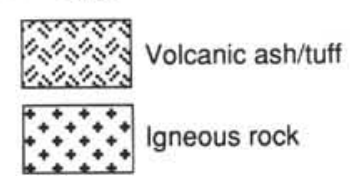

Volcanic sandstone

Silty sand/sandy silt

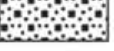
$\left[\begin{array}{l}\because \\ \because \because 3 \\ \hdashline\end{array}\right.$

Figure 2 (continued).

\section{Lithostratigraphic Unit VI (866-953 mbsf)}

In this unit lithified volcanic sandstone grades downward to very coarse late Miocene volcaniclastic sandstone and conglomerate. Two clasts from the same horizon ( $885 \mathrm{mbsf}$ ) are non-vesicular, and include an olivine + augite-phyric basalt with rare plagioclase phenocrysts, and an olivine + augite-phyric andesite lacking plagioclase phenocrysts. Minor alteration affects both samples. Sample 134-832B-78R-1, 0-3 $\mathrm{cm}$, is an olivine + augite-phyric basalt with phenocrysts of augite $(17 \%, 0.5-3.0 \mathrm{~mm})$, olivine $(4 \%, 0.3-3.0 \mathrm{~mm})$, and plagioclase $(3 \%$, $0.3-1.0 \mathrm{~mm}$ ). Augite phenocrysts are euhedral to subhedral with minor chlorite alteration along cracks and inclusions. Olivine phenocrysts are subhedral to anhedral, rather corroded, and with alteration varying from almost none to $90 \%$. Large olivine crystals are more euhedral and more altered. Plagioclase is mostly subhedral, and grades down to microphenocryst-sized crystals. Occasional microphenocrysts of Fe-
Ti oxides are found. Groundmass is rather glassy, and partially altered to palagonite, with flow-orientated plagioclase laths and minute granular opaques and pyroxenes.

\section{Lithostratigraphic Unit VII (953-1107 mbsf)}

This unit consists of $60 \%$ lithified volcanic breccia, and the remainder is lithified volcanic sandstone, siltstone, and vitric ash with pumice fragments. The top of the unit has early Middle Miocene microfossils, so the single $\mathrm{K}-\mathrm{Ar}$ age (Rex, this volume) for one clast (Sample $134-832 \mathrm{~B}-100 \mathrm{R}-3,146-149 \mathrm{~cm}$ ) of $5.66 \mathrm{Ma}$ seems likely to be too young, possibly due to incipient alteration. Volcanic clasts in the breccia are subangular to rounded, commonly $5 \mathrm{~mm}$ to $2 \mathrm{~cm}$ in size, and are vesicular, with voids and veins often filled with zeolite; they are always supported by the volcanic sandstone matrix. Despite the shipboard lithostratigraphic description as basaltic breccia (Collot, 
Greene, Stokking, et al., 1992), only two analyzed samples are basalt and the remaining six analyzed samples are andesite. Several phenocryst assemblages occur. All volcanic clasts from this unit characteristically contain orthopyroxene. One basalt contains phenocrysts of olivine and augite with trace amounts of orthopyroxene, and the other contains phenocrysts of plagioclase and two pyroxenes. Andesites show several phenocryst assemblages, including augite only, olivine + plagioclase + augite, olivine + plagioclase + two pyroxenes, and plagioclase + two pyroxenes. Studied samples are generally vesicular, and some show extensive alteration, although altered samples were avoided for our analytical study.

Sample 134-832B-94R-1, 34-37 cm, representative of the two pyroxene andesite clasts in this unit, contains euhedral to subhedral phenocrysts of augite $(18 \%, 0.3-2.5 \mathrm{~mm})$, plagioclase $(13 \%, 0.3-1.5$ $\mathrm{mm})$, olivine ( $2 \%, 0.3-0.8 \mathrm{~mm})$, and orthopyroxene $(2 \%, 0.3-1.5 \mathrm{~mm})$. Olivine is the most altered phenocryst phase, ranging from $0 \%$ to $80 \%$ altered. Both augite and orthopyroxene are slightly altered, and alteration of plagioclase is negligible. Olivine often occurs as microphenocrysts. Groundmass is composed of plagioclase laths, minute acicular pyroxenes and brownish glass partly altered to palagonite.

One picritic basalt (134-832B-94R-2, 23-26 cm) contains abundant phenocrysts of olivine $(20 \%)$ and augite $(5 \%)$. Olivine is completely altered to chlorite and clay minerals. The other basalt (134832B-99R-3, 53-57 cm) contains phenocrysts of plagioclase and two pyroxenes, and is also highly altered.

\section{Site $\mathbf{8 3 3}$}

\section{Lithostratigraphic Unit III (376-578 mbsf)}

This unit consists of black volcanic sandstones and fine-grained basaltic breccia. Volcanic clasts range in size from sand grains up to $11 \mathrm{~cm}$ across, and are generally vesicular, subangular to rounded, and are set in a matrix of unsorted volcanic sandstone. Of seven analyzed samples, six are basaltic and one is an andesite. Phenocryst assemblages of the basaltic clasts include augite + plagioclase + olivine, augite only, and olivine + augite. Samples with augite phenocrysts alone have up to 60 modal\% augite. The andesite has the phenocryst assemblage plagioclase + two pyroxenes + hornblende, with trace olivine. Vesicular and non-vesicular lavas occur, and some samples show moderate alteration.

Sample 134-833B-37R-1, 42-43 cm, is typical of basaltic clasts in this unit, and contains mostly subhedral phenocrysts of augite $(20 \%, 0.3-3.0 \mathrm{~mm})$, plagioclase $(10 \%, 0.3-1.0 \mathrm{~mm})$, and olivine $(8 \%$, $0.3-1.5 \mathrm{~mm}$ ). Olivine is completely altered to serpentine, chlorite, and minor calcite. Plagioclase and augite are mainly fresh. The former show dusty zones composed of minute glass and pyroxene inclusions. Microphenocryst-sized $(0.03-0.3 \mathrm{~mm})$ plagioclase and olivine are abundant, and $\mathrm{Fe}-\mathrm{Ti}$ oxide minerals are less abundant. Plagioclase, pyroxenes and subordinate opaque minerals are present in the intergranular groundmass.

\section{Lithostratigraphic Unit V (830-1001 mbsf)}

Basaltic sills are the main component of this unit, and at least seven intrusive units are recognized. The boundaries of different intrusive units were recognized by interbedded sedimentary rocks, chilled margins and oxidized zones. K-Ar dating (Samples 134-833B-82R-4, $100-105 \mathrm{~cm}$, and 134-833B-99R-5, 71-77 cm) yielded ages of 3.30 $\pm 0.30 \mathrm{Ma}$ and $3.65 \pm 0.18 \mathrm{Ma}$ for two sills. Samples for petrographic and geochemical study were taken from almost all the cores between 134-833B-81R and $-99 \mathrm{R}$, except $-87 \mathrm{R}$ and $-89 \mathrm{R}$. Among 31 samples analyzed, 15 are basalts $\left(51.6 \%-53.0 \% \mathrm{SiO}_{2}\right)$ and 16 are basaltic andesites $\left(53.0-57.4 \mathrm{wt} \% \mathrm{SiO}_{2}\right)$. Petrographic features do not change much between different intrusive units. One significant petrographic difference observed through the entire sill sequence is that the upper sills are more porphyritic than those in the lower half of the sill complex. This change is abrupt, and occurs between Samples 134-
833B-90R-4, 116-119 cm, and 134-833B-91R-2, 81-85 cm (Fig. 3). Phenocryst assemblages are dominated by plagioclase + augite + olivine; a few samples lack olivine.

The upper sill units are porphyritic plagioclase + augite + olivinephyric basalts to basaltic andesites in which the most abundant phenocrysts are plagioclase, followed by augite and olivine, and rare phenocrysts of Fe-Ti oxides. Plagioclase phenocrysts are euhedral to subhedral, mostly $2-8 \mathrm{~mm}$ long, with weak zoning. Augite phenocrysts are equant, granular subhedral, mostly $0.3-1.5 \mathrm{~mm}$ long. Olivine phenocrysts are $0.3-1 \mathrm{~mm}$ long, euhedral to subhedral, and usually altered to greenish or brownish clay minerals, or calcite. There are also sparse microphenocrysts of Fe-Ti oxide $(1 \%-2 \%, 0.1-0.2 \mathrm{~mm})$. The quenched groundmass contains acicular plagioclase $(\sim 0.1 \mathrm{~mm}$ long) laths randomly oriented in brown glass, and rare small granular augite crystals. Groundmass Fe-Ti oxide minerals are rare, except in Sample 134833B-81R-3, 1-4 cm, in which both acicular and granular titanomagnetite occur with acicular plagioclase and granular augite. The average phenocryst abundance is $47 \%(n=10)$, made up of $31 \%$ plagioclase, $10 \%$ augite, and $4.6 \%$ olivine. In contrast, these values change to $32 \%$, $20 \%, 7 \%$, and $3.4 \%(n=11)$, respectively, for the lower sill units.

The lower sill units are also porphyritic augite + olivine-phyric basalts to basaltic andesites with similar relative abundances of phenocryst minerals, which show similar petrographic features to those in the upper sills. Olivine phenocrysts are absent in some samples. The groundmass is almost holocrystalline, with microphenocrystsized prismatic plagioclase, granular augite and opaque minerals, altered olivine, and interstitial glassy mesostasis.

\section{MINERALOGY}

Extensive electron microprobe analyses were made for three volcanic clasts from Site 832 and two volcanic clasts and two sill samples from Site 833. Representative analyses of each phase are listed in Tables 1-4, and are shown in Figures 4 and 5.

\section{Olivine}

Compositions of olivine were determined for only two samples, a basaltic clast from lithostratigraphic Unit IV of Hole 832B, and another from lithostratigraphic Unit III of Hole 833B. Olivine phenocrysts in Sample 134-832B-55R-4, 121-125 cm, are $\mathrm{Fo}_{75-76}$, and groundmass olivine is $\mathrm{Fo}_{71-74}$. Olivine phenocryst cores have almost identical $\mathrm{Fe} / \mathrm{Mg}$ values to those of coexisting augite and orthopyroxene, indicating an equilibrium relationship among these phases. Olivine phenocrysts in Sample 134-833B-34R-2, 123-127 cm, are $\mathrm{Fo}_{74-76}$, and rims are $\mathrm{Fo}_{66-67}$. NiO contents of phenocrystic olivine $\left(\mathrm{Fo}_{76}\right)$ in the former sample are $0.23 \%$, and $0.10 \%$ for the latter sample.

\section{Feldspars}

Compositions of plagioclase phenocrysts were determined for all seven samples, and show that rim and groundmass compositions are more albitic. Alkali feldspar is only found as a groundmass phase in sill sample 134-833B-99R-5, 71-77 cm. Analyzed plagioclase phenocryst core compositions (Fig. 4) generally fall within a small compositional range $\left(\mathrm{An}_{75}-\mathrm{An}_{92}\right)$. Andesite clast 134-833B-36R-1, 96-99 $\mathrm{cm}$, contains plagioclase phenocrysts that are more albitic than other samples, and two compositional groups of plagioclase phenocrysts $\left(\mathrm{An}_{79-92}\right.$ and $\left.\mathrm{An}_{65}\right)$ are found. Two compositional groups also occur in the upper part of sill Sample 134-833B-82R-4, 100-105 cm ( $\mathrm{An}_{83-92}$ and $A n_{52-65}$ ), in which the most albitic composition is similar to that of plagioclase phenocrysts in the lower analyzed sill sample (134-833B99R-5, 71-77 cm, $\mathrm{An}_{57}$ ).

\section{Clinopyroxene}

Clinopyroxene compositions were determined for all seven samples (Fig. 5). Most phenocryst phases are augitic, except a few grains 


\section{A}
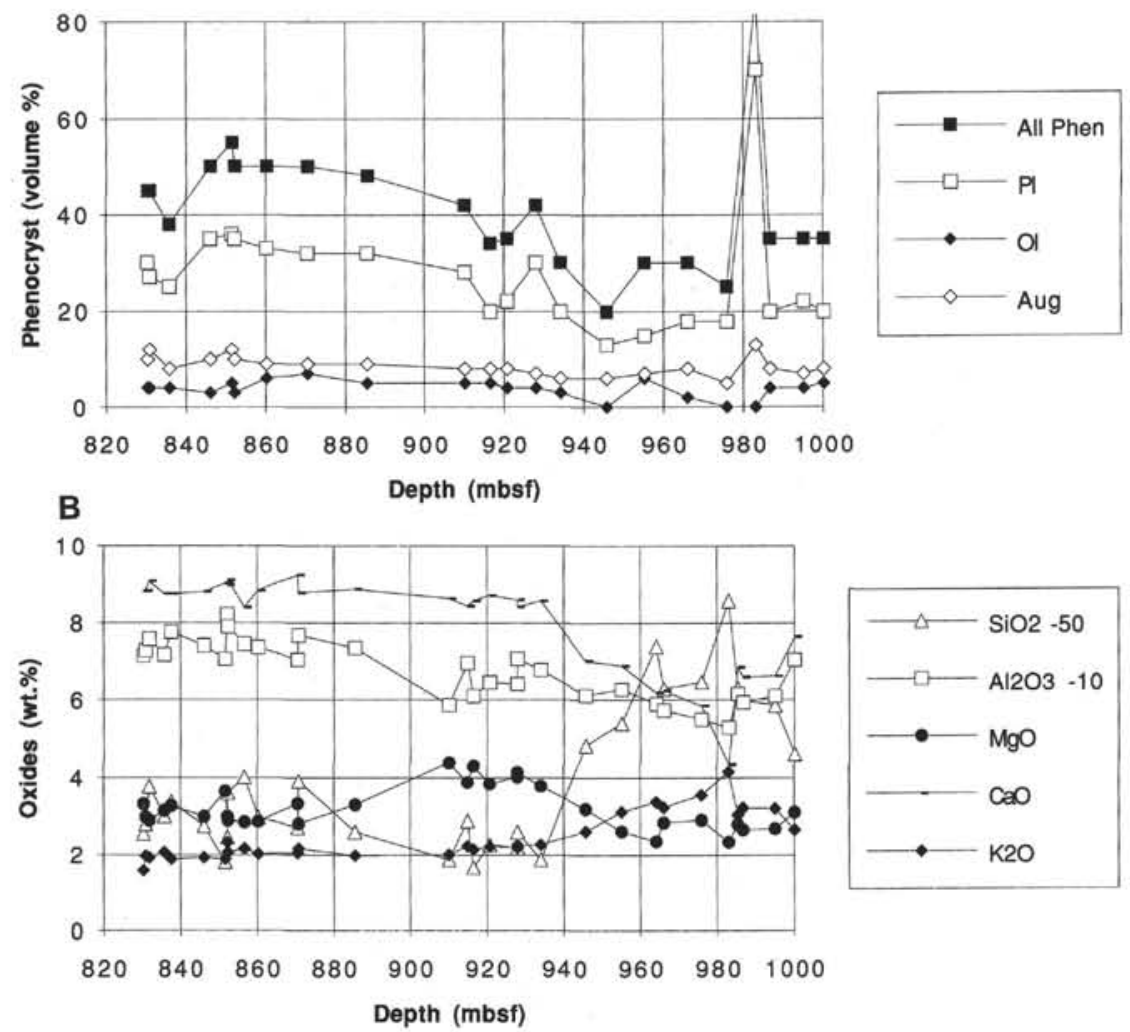

Figure 3. A. Modal percentage of phenocryst minerals in sill samples plotted against depth (mbsf). B. Chemical composition (wt\%) of sill samples plotted against depth (mbsf). In order to show all the oxide data, $50 \%$ was subtracted from silica content, $10 \%$ from alumina content, $5 \%$ from total $\mathrm{Fe}$ as $\mathrm{FeO}\left(\mathrm{FeO}^{*}\right)$.

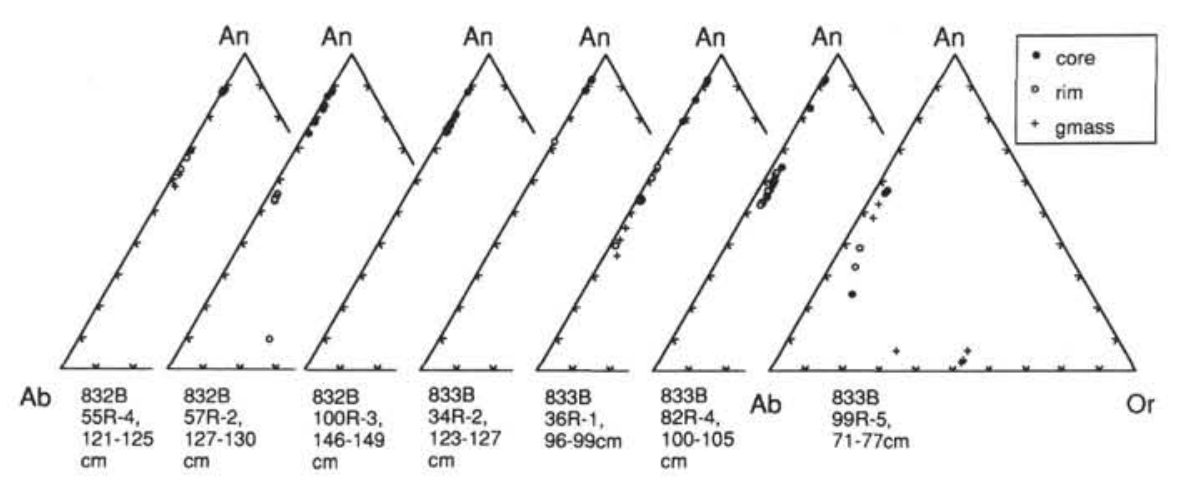

Figure 4. Plagioclase compositions of volcanic clasts and sills of the North Aoba Basin plotted in the An-Ab-Or triangle.

that are diopsidic (Sample 134-832B-55R-4, 121-125 cm) or salitic (Sample 134-833B-34R-2, 123-127 cm) fields. Rim compositions are generally more $\mathrm{Fe}$-rich and $\mathrm{Ca}$-poor. Pigeonite and subcalcic augite are present in the groundmass of sill sample, 134-833B-99R-5, $71-77 \mathrm{~cm}$, and pigeonite occurs as phenocryst rims on augite in volcanic clast, Sample 134-833B-36R-1, 96-99 cm. A relatively wide range of phenocryst core compositions occurs in andesite clast, Sample 134-832B-100R-3, 146-149 cm. However step scan profiles of three large phenocrysts reveal no systematic zoning patterns, except for a slight decrease of Wo at phenocryst rims.

\section{Orthopyroxene}

Orthopyroxene phenocryst compositions were determined in three clasts (Fig. 5). In all cases, compositions are bronzitic $\left(\mathrm{En}_{76}, \mathrm{En}_{76}\right.$, and $\mathrm{En}_{73}$ ), with little variation in core composition but slightly more Fe-rich phenocryst rims and groundmass compositions.

\section{Fe-Ti Oxides}

Fe-Ti oxides compositions were determined for three samples, and are mostly titanomagnetite, although there are rare grains of ilmenite 
Table 1. Representative microprobe analyses (weight \%) and atomic proportions of plagioclases from North Aoba Basin lava clasts and sills.

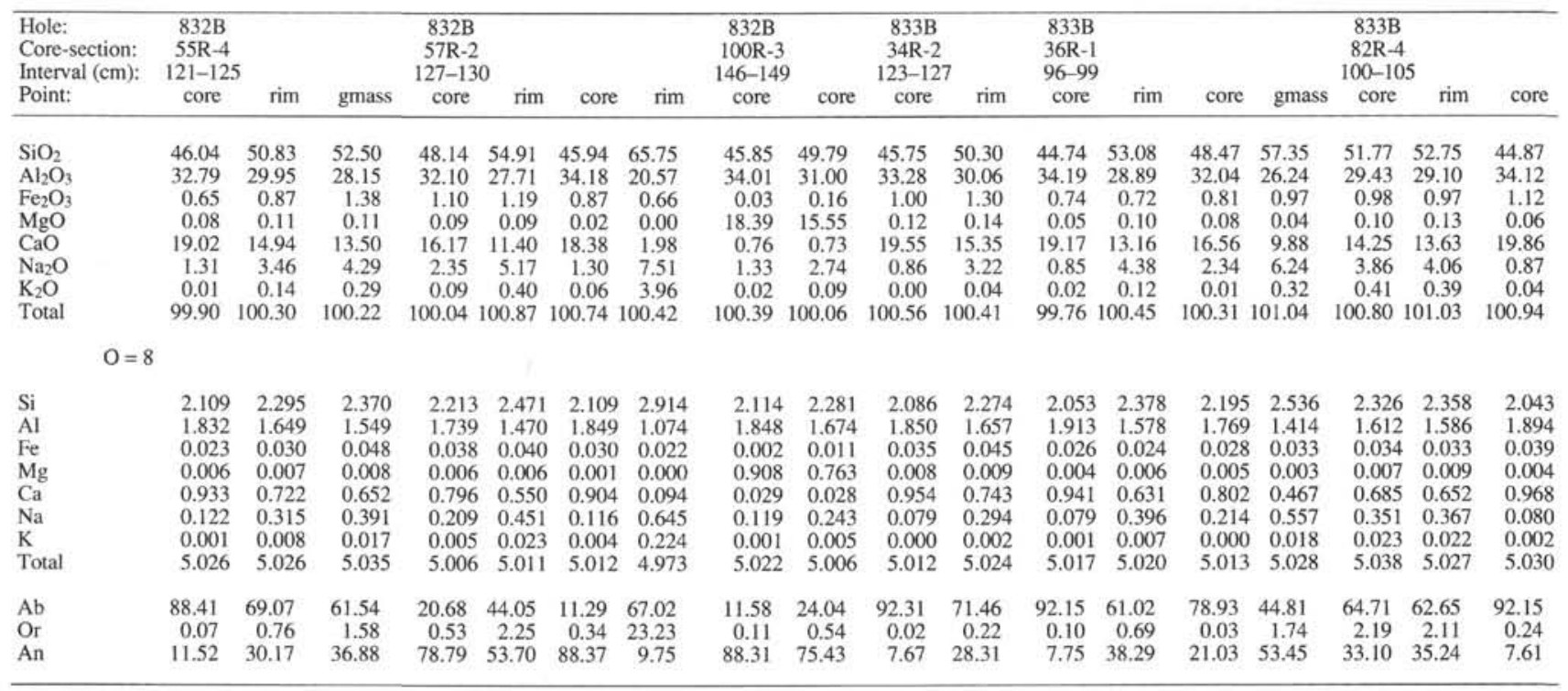

Table 2. Representative electron microprobe analyses (weight \%) and atomic proportions of olivines from North Aoba Basin lava clasts and sills.

\begin{tabular}{|c|c|c|c|c|c|}
\hline $\begin{array}{l}\text { Hole: } \\
\text { Core-section: } \\
\text { Interval }(\mathrm{cm}) \text { : } \\
\text { Point: }\end{array}$ & $\begin{array}{c}832 \mathrm{~B} \\
55 \mathrm{R}-4 \\
121-125 \\
\text { relict }\end{array}$ & gmass & gmass & $\begin{array}{c}833 \mathrm{~B} \\
34 \mathrm{R}-2 \\
123-127 \\
\text { core }\end{array}$ & rim \\
\hline $\begin{array}{l}\mathrm{SiO}_{2} \\
\mathrm{TiO}_{2} \\
\mathrm{Al}_{2} \mathrm{O}_{3} \\
\mathrm{MgO} \\
\mathrm{CaO} \\
\mathrm{MnO} \\
\mathrm{FeO} \\
\mathrm{NiO} \\
\text { Total }\end{array}$ & $\begin{array}{r}38.42 \\
0.03 \\
0.00 \\
39.42 \\
0.16 \\
0.53 \\
21.22 \\
0.23 \\
100.01\end{array}$ & $\begin{array}{r}37.66 \\
0.02 \\
0.00 \\
37.20 \\
0.24 \\
0.43 \\
22.72 \\
0.00 \\
98.27\end{array}$ & $\begin{array}{r}36.48 \\
0.08 \\
0.04 \\
32.99 \\
0.30 \\
0.79 \\
27.97 \\
0.00 \\
98.65\end{array}$ & $\begin{array}{r}38.90 \\
0.01 \\
0.00 \\
39.45 \\
0.21 \\
0.00 \\
21.93 \\
0.10 \\
100.60\end{array}$ & $\begin{array}{r}37.72 \\
0.12 \\
0.01 \\
33.51 \\
0.27 \\
0.46 \\
28.43 \\
0.04 \\
100.56\end{array}$ \\
\hline \multicolumn{6}{|c|}{$\mathrm{O}=4$} \\
\hline $\begin{array}{l}\mathrm{Si} \\
\mathrm{Ti} \\
\mathrm{Al} \\
\mathrm{Mg} \\
\mathrm{Ca} \\
\mathrm{Mn} \\
\mathrm{Fe}^{2+} \\
\mathrm{Ni} \\
\text { Total }\end{array}$ & $\begin{array}{l}0.991 \\
0.001 \\
0.000 \\
1.532 \\
0.005 \\
0.012 \\
0.463 \\
0.005 \\
3.009\end{array}$ & $\begin{array}{l}0.996 \\
0.000 \\
0.000 \\
1.481 \\
0.007 \\
0.010 \\
0.509 \\
0.000 \\
3.003\end{array}$ & $\begin{array}{l}0.989 \\
0.002 \\
0.001 \\
1.347 \\
0.009 \\
0.018 \\
0.642 \\
0.000 \\
3.008\end{array}$ & $\begin{array}{l}0.997 \\
0.000 \\
0.000 \\
1.522 \\
0.006 \\
0.000 \\
0.476 \\
0.002 \\
3.003\end{array}$ & $\begin{array}{l}1.000 \\
0.002 \\
0.000 \\
1.337 \\
0.008 \\
0.011 \\
0.638 \\
0.001 \\
2.997\end{array}$ \\
\hline $\begin{array}{l}\text { Fo } \\
\text { Fa }\end{array}$ & $\begin{array}{l}76.33 \\
23.67\end{array}$ & $\begin{array}{l}74.05 \\
25.95\end{array}$ & $\begin{array}{l}67.12 \\
32.88\end{array}$ & $\begin{array}{l}76.18 \\
23.82\end{array}$ & $\begin{array}{l}67.32 \\
32.68\end{array}$ \\
\hline
\end{tabular}

(Sample 134-832B-57R-2, 127-130 cm). All the analyzed samples were relatively poor in ülvospinel molecule. Phenocryst-sized grains are more $\mathrm{Mg}$-rich and poorer in $\mathrm{Al}$ and $\mathrm{Ti}$ than groundmass grains.

\section{WHOLEROCK GEOCHEMISTRY}

\section{Introduction}

Three aspects of the geochemistry of the drilled igneous rocks require discussion. First, it is important to determine the rocks' compositional variability and affinities. Second, the drilled rocks should be compared with lavas and shallow intrusives on the islands surrounding the NAB to test for possible correlations, and establish the time-space relationships of magmatism in the central portion of the New Hebrides Island Arc. Third, it will be useful to establish the physico-chemical aspects of magma generation and the variation of source mantle compositions. Here we address only the first and second of the above aspects of geochemistry of the igneous rocks drilled at Sites 832 and 833. The isotopic compositions of igneous rocks recovered from the $\mathrm{NAB}$ during Leg 134 drilling are detailed and discussed in Briqueu et al. (this volume).

Major and trace element analyses of samples from Sites 832 and 833 are listed in Table 5, and REE data are given in Table 6. Harker diagrams for major and trace elements are shown in Figure 6.

\section{Compositional Variability and Affinities}

\section{Site $832 B$}

Clasts are dominantly basaltic, a feature of the New Hebrides Island Arc as a whole, but andesites are also present, particularly in the basal Unit VII. Macfarlane et al. (1988) compiled approximately 400 wholerock analyses of lavas from the New Hebrides Island Arc and pointed out the difficulty in classifying these arc lava suites, particularly with respect to tholeiitic vs. calc-alkaline, and alkaline vs. subalkaline classification. In Miyashiro's (1974) $\mathrm{FeO}^{*} / \mathrm{MgO}$ vs. $\mathrm{SiO}_{2}$ plot to discriminate tholeiitic from calc-alkaline lavas (Fig. 7A), most Hole $832 \mathrm{~B}$ clasts plot in the tholeiitic field, or close to the tholeiite-calc-alkaline divide. Only lithostratigraphic Unit VII is clearly calc-alkaline. However, tholeiitic fractionation trends typically show significant Fe-enrichment, whereas the Units II, III, IV, and VI clasts from this hole show decreasing $\mathrm{FeO}^{*}$ (and $\mathrm{TiO}_{2}$ and V) with advancing fractionation. Therefore, for classification we rely mainly on a $\mathrm{SiO}_{2}-\mathrm{K}_{2} \mathrm{O}$ plot (Fig. 7B).

There are systematic compositional differences of volcanic clasts recovered from different lithostratigraphic units. Despite slight variations in phenocryst assemblages, samples from the upper Pliocene to lower Pleistocene epiclastic units (lithostratigraphic Units II, III, $\mathrm{IV}$, and $\mathrm{VI})$ are all low $\mathrm{Al}_{2} \mathrm{O}_{3}(1 \%-16 \%)$ medium- to high- $\mathrm{K}$ basalts with $\mathrm{FeO}^{*} / \mathrm{MgO}$ values mainly from $1-2$.

In contrast, volcanic clasts from the late Miocene epiclastic lava breccias (lithostratigraphic Unit VII) are mostly low- to medium-K calc-alkaline andesites, as shown in Fig. 7B, but this suite also includes Sample 134-832B-94R-2, 23-26 cm, a low-K picritic basalt with $13 \% \mathrm{MgO}$. Note that these andesites are petrographically characterized by the presence of orthopyroxene phenocrysts. At any $\mathrm{SiO}_{2}$ 
Table 1 (continued).

\begin{tabular}{|c|c|c|c|c|c|c|}
\hline $\begin{array}{l}\text { Hole: } \\
\text { Core-section: } \\
\text { Interval (cm): } \\
\text { Point: }\end{array}$ & $\begin{array}{c}833 \mathrm{~B} \\
82 \mathrm{R}-4 \\
100-105 \\
\text { gmass }\end{array}$ & $\begin{array}{c}833 \mathrm{~B} \\
99 \mathrm{R}-5 \\
5 \text { 71-77 } \\
\text { core }\end{array}$ & $\begin{array}{ll}5 & \\
7 & \\
& \mathrm{rim}\end{array}$ & gmass & $s$ gmass & is gmass \\
\hline $\begin{array}{l}\mathrm{SiO}_{2} \\
\mathrm{Al}_{2} \mathrm{O}_{3} \\
\mathrm{Fe}_{2} \mathrm{O}_{3} \\
\mathrm{MgO} \\
\mathrm{CaO} \\
\mathrm{Na}_{2} \mathrm{O} \\
\mathrm{K}_{2} \mathrm{O} \\
\text { Total }\end{array}$ & $\begin{array}{r}53.36 \\
28.23 \\
1.33 \\
0.12 \\
13.04 \\
4.49 \\
0.50 \\
101.07\end{array}$ & $\begin{array}{r}53.67 \\
27.74 \\
1.18 \\
0.09 \\
12.46 \\
4.59 \\
0.59 \\
100.32\end{array}$ & $\begin{array}{r}58.77 \\
25.25 \\
0.78 \\
0.02 \\
8.37 \\
6.49 \\
0.94 \\
100.62\end{array}$ & $\begin{array}{r}65.73 \\
18.59 \\
0.45 \\
0.01 \\
0.62 \\
5.23 \\
9.12 \\
99.75\end{array}$ & $\begin{array}{r}61.86 \\
23.06 \\
0.44 \\
0.02 \\
5.35 \\
7.71 \\
1.90 \\
100.34\end{array}$ & $\begin{array}{r}56.24 \\
26.32 \\
0.77 \\
0.03 \\
10.70 \\
5.69 \\
0.74 \\
100.49\end{array}$ \\
\hline $\begin{array}{l}\mathrm{Si} \\
\mathrm{Al} \\
\mathrm{Fe} \\
\mathrm{Mg} \\
\mathrm{Ca} \\
\mathrm{Na} \\
\mathrm{K} \\
\text { Total }\end{array}$ & $\begin{array}{l}2.387 \\
1.540 \\
0.045 \\
0.008 \\
0.624 \\
0.405 \\
0.029 \\
5.038\end{array}$ & $\begin{array}{l}2.413 \\
1.521 \\
0.041 \\
0.006 \\
0.600 \\
0.417 \\
0.034 \\
5.032\end{array}$ & $\begin{array}{l}2.601 \\
1.362 \\
0.026 \\
0.001 \\
0.397 \\
0.580 \\
0.053 \\
5.020\end{array}$ & $\begin{array}{l}2.958 \\
1.020 \\
0.016 \\
0.001 \\
0.030 \\
0.475 \\
0.523 \\
5.023\end{array}$ & $\begin{array}{l}2.732 \\
1.242 \\
0.015 \\
0.001 \\
0.253 \\
0.688 \\
0.107 \\
5.038\end{array}$ & $\begin{array}{l}2.511 \\
1.433 \\
0.026 \\
0.002 \\
0.511 \\
0.513 \\
0.042 \\
5.038\end{array}$ \\
\hline $\begin{array}{l}\mathrm{Ab} \\
\mathrm{Or} \\
\mathrm{An}\end{array}$ & $\begin{array}{r}58.98 \\
2.69 \\
38.32\end{array}$ & $\begin{array}{r}57.08 \\
3.20 \\
39.71\end{array}$ & $\begin{array}{r}38.50 \\
5.13 \\
56.36\end{array}$ & $\begin{array}{r}2.93 \\
50.86 \\
46.21\end{array}$ & $\begin{array}{l}24.12 \\
10.20 \\
65.67\end{array}$ & $\begin{array}{r}47.96 \\
3.93 \\
48.12\end{array}$ \\
\hline
\end{tabular}

level, these calc-alkaline lavas are distinctively poorer in $\mathrm{K}_{2} \mathrm{O}$ (and $\mathrm{Rb}, \mathrm{Sr}$, and $\mathrm{Ba}$ ) than the volcanic clasts from the upper lithostratigraphic units, are significantly richer in $\mathrm{MgO}, \mathrm{Cr}$, and $\mathrm{Ni}$, and have similar $\mathrm{Zr}$ and $\mathrm{Y}$ contents.

The elongate field defined by basalts $\left(<51 \% \mathrm{SiO}_{2}\right.$ and $\left.>6 \% \mathrm{MgO}\right)$ from lithostratigraphic Units II, III, IV, and VI on the plots of $\mathrm{SiO}_{2}$ vs. $\mathrm{TiO}_{2}, \mathrm{~K}_{2} \mathrm{O}, \mathrm{P}_{2} \mathrm{O}_{5}, \mathrm{FeO}^{*}, \mathrm{Ce}, \mathrm{Y}$, and $\mathrm{Zr}$, are all at high angles to typical crystal fractionation trends, decreasing with increasing $\mathrm{SiO}_{2}$, rather than increasing with fractionation as expected. This spread of compositions may reflect a spread in the primary magma compositions of these lavas, with relatively higher pressure, lower degrees of partial melting magmas having lower- $\mathrm{SiO}_{2}$, higher $\mathrm{FeO}^{*}$, higher $\mathrm{K}_{2} \mathrm{O}$, and higher high-field-strength elements (HFSE), compared to lower pressure, higher-degree melts. This point is taken up further on.

\section{Site 833}

Unlike Hole 832B, Hole 833B lacks any Miocene rocks. Volcanic clasts come only from lithostratigraphic Unit III in the Pliocene section, and include ankaramite, olivine + augite-phyric basalt, and one hornblende andesite. All are low-K compositions, contrasting with the medium- to high- $\mathrm{K}$ basalts and andesites in Hole 832B, including volcanic clasts from the broadly age-correlated lithostratigraphic Unit IV Hole 832B. At a given $\mathrm{SiO}_{2}$ content, these $833 \mathrm{~B}$ samples have significantly lower $\mathrm{K}_{2} \mathrm{O}$, total alkalies, $\mathrm{P}_{2} \mathrm{O}_{5}, \mathrm{TiO}_{2}, \mathrm{Rb}$, $\mathrm{Sr}$, and $\mathrm{Ba}$ contents than lava clasts from Site 832B.

Lithostratigraphic Unit V sill basalts and andesites are clearly separated on the Harker diagrams from the volcanic clasts in both holes, and define a coherent fractionation trend (Fig. 6). The upper sill samples have $\mathrm{SiO}_{2}$ contents from $51.8 \%$ to $54.0 \%$, whereas the lower sills can be divided into two compositional groups (see Fig. 3B). From Cores 134-833B-91R-1 to 93R-1, basalts with $\mathrm{SiO}_{2}$ contents between $51.6 \%$ and $52.9 \%$ form the $\mathrm{SiO}_{2}$-poor end of the variation trend, and pass downward from Core 134-833B-94R-2 to -99R-6 into andesites with $\mathrm{SiO}_{2}$ contents between $54.6 \%$ and $58.6 \%$. All sill samples are characteristically high in $\mathrm{K}_{2} \mathrm{O}$, and fall mostly in the high- $\mathrm{K}$ basalt-andesite field, although a few plot in the shoshonite field. They contain higher $\mathrm{P}_{2} \mathrm{O}_{5}, \mathrm{TiO}_{2}$, and total $\mathrm{Fe}$ than any volcanic clasts at similar $\mathrm{SiO}_{2}$ contents. Compositional trends for the sill samples, with a notable deflection around $54 \% \mathrm{SiO}_{2}$ to lower $\mathrm{Al}_{2} \mathrm{O}_{3}$ and $\mathrm{CaO}$ contents, suggest an earlier olivine(+pyroxene?)-controlled fractionation followed by a later plagioclase-dominated fractionation trend.

\section{Trace Elements Compositions}

\section{Hole $832 B$}

In Figure 8, rare earth element (REE) patterns and Pearce-type mid-ocean ridge basalt (MORB)-normalized trace element patterns are given for representative samples from lithostratigraphic Unit VII in Hole 832B. These late Miocene calc-alkaline clasts have REE patterns (Fig. 8A) with flatter heavy rare earth element (HREE) and steeper La to Nd intervals than clasts from other lithostratigraphic units in either hole. They also have distinctive patterns on the element variation diagrams in Figure 8B, showing convex curves increasing uniformly from $\mathrm{Sr}$ to $\mathrm{Th}$, and higher normalized $\mathrm{Ce} / \mathrm{P}$ and $\mathrm{Zr} / \mathrm{Sm}$ values than rocks from any other units, including the sills in Hole 833B.

For Hole 832B lithostratigraphic Units II, III, IV, and VI, REE data are only available for clasts from Units IV and VI. Although not comagmatic, basaltic clasts with close to $9 \% \mathrm{MgO}$ from each hole have similar slightly light rare earth element (LREE)-enriched $\left([\mathrm{La} / \mathrm{Sm}]_{\mathrm{N}}\right.$ from 1.2-1.9) patterns (Fig. 9A) with sloping HREE patterns.

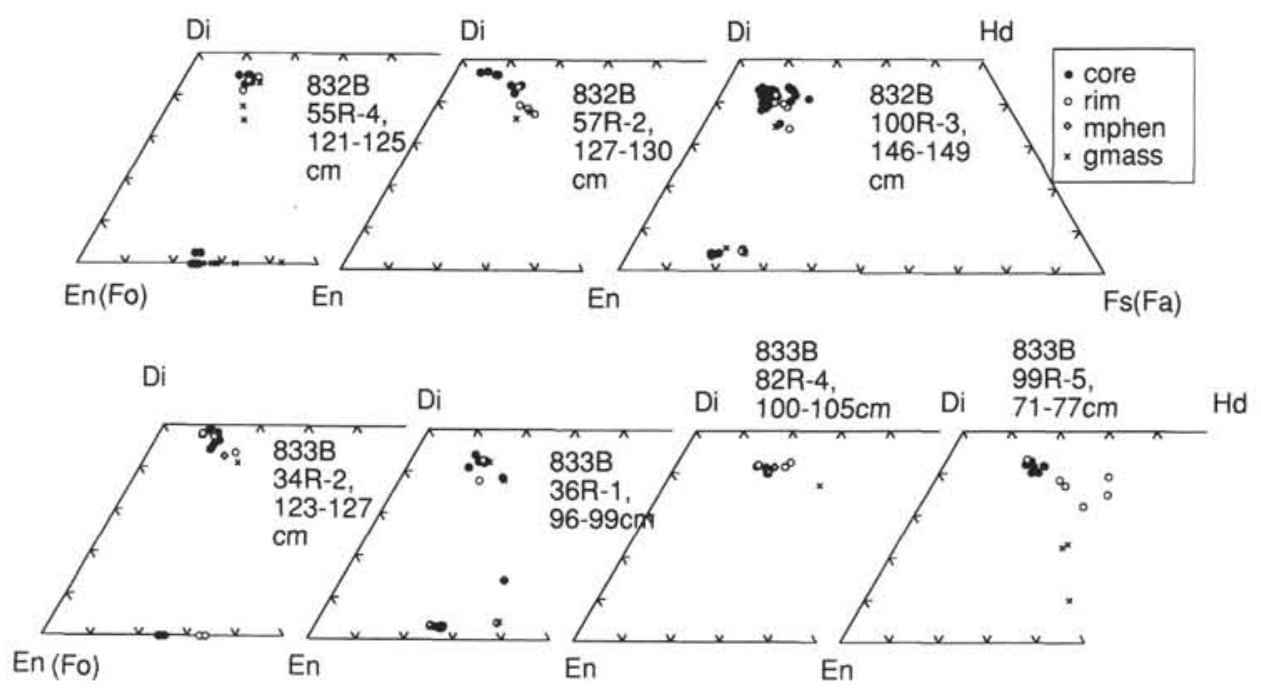

Figure 5. Olivine and pyroxene compositions of volcanic clasts and sill of the North Aoba Basin plotted in the pyroxene quadrilateral. Olivine compositions shown along the $\mathrm{Fe}-\mathrm{Mg}$ join. 
T. HASENAKA ET AL.

Table 3. Representative microprobe analyses (weight \%) and atomic proportions of pyroxenes from North Aoba Basin lava clasts and sills.

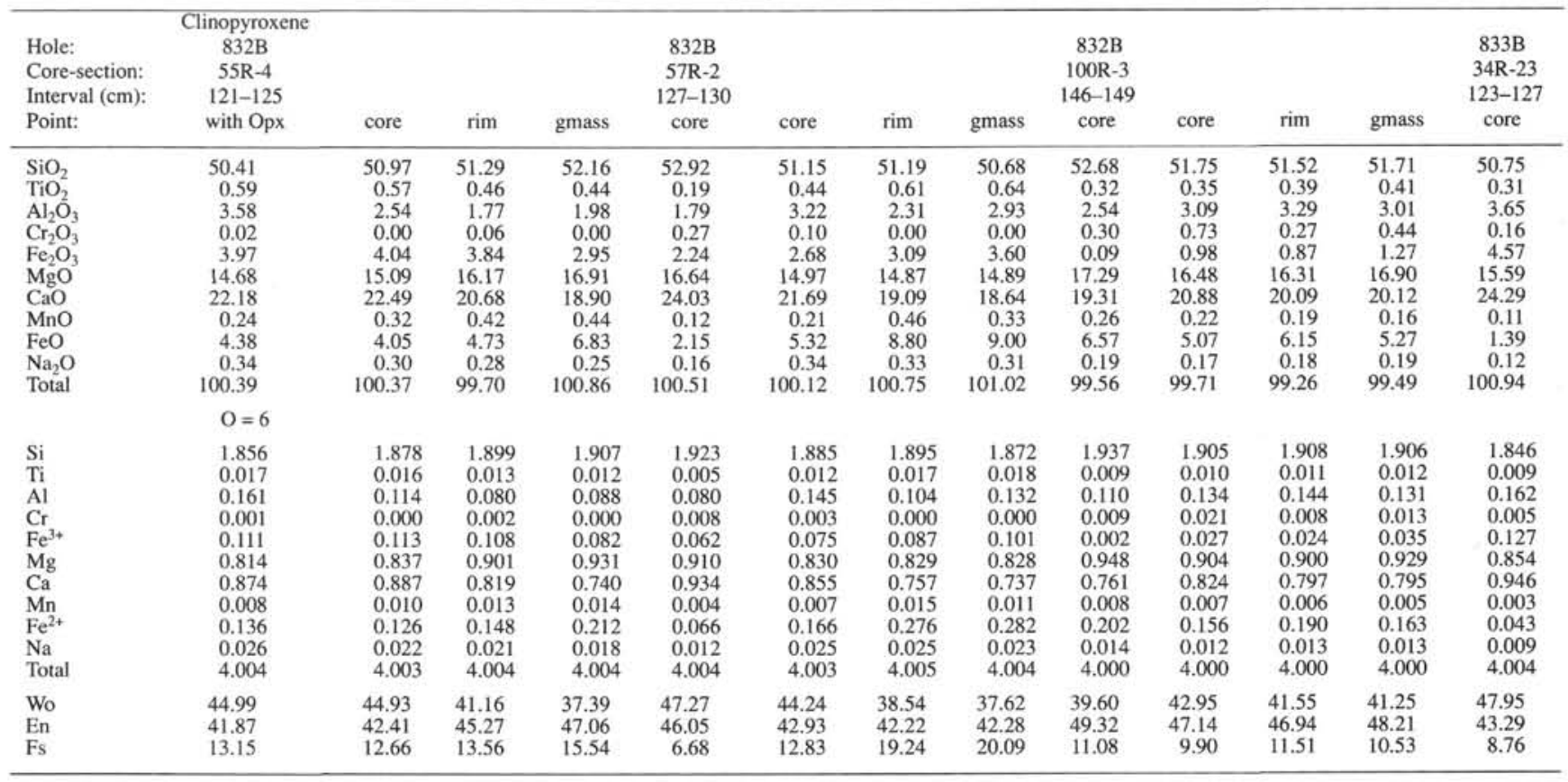
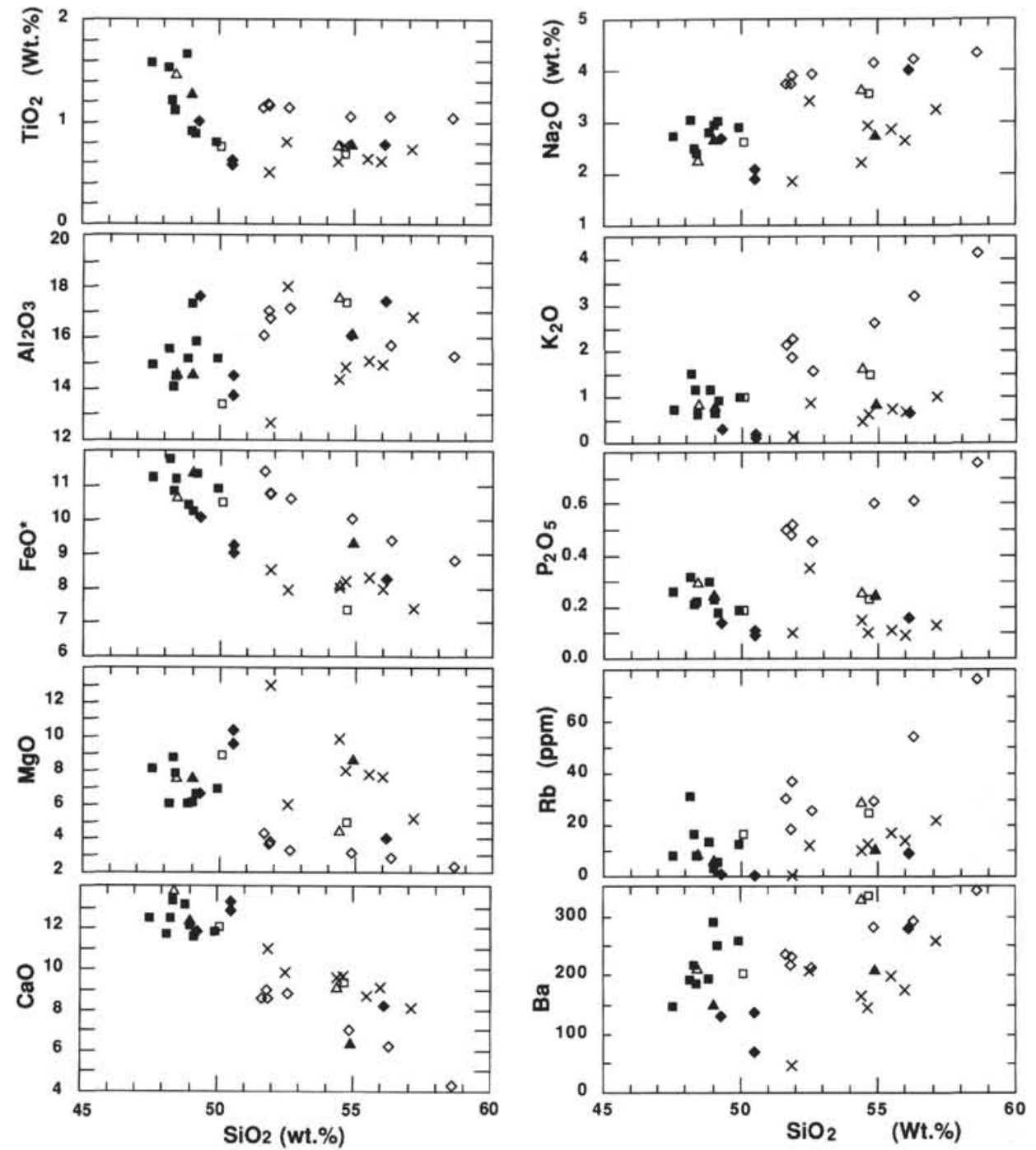

Figure 6. Harker diagrams for volcanic clasts and sill of the North Aoba Basin. Hole 832B. 
Table 3 (continued).

\begin{tabular}{|c|c|c|c|c|c|c|c|c|c|c|c|}
\hline $\begin{array}{l}\text { Hole: } \\
\text { Core-section: } \\
\text { Interval }(\mathrm{cm}) \text { : } \\
\text { Point: }\end{array}$ & $\begin{array}{c}833 \mathrm{~B} \\
34 \mathrm{R}-23 \\
123-127 \\
\text { gmass }\end{array}$ & $\begin{array}{c}833 \mathrm{~B} \\
6 \mathrm{R}-18 \\
96-99 \\
\text { core }\end{array}$ & out rind & gmass & $\begin{array}{c}833 B \\
2 R-49 \\
100-105 \\
\text { core }\end{array}$ & rim & gmass & $\begin{array}{c}833 \mathrm{~B} \\
9 \mathrm{R}-5 \\
71-77 \\
\text { core }\end{array}$ & rim & mphen & mphen \\
\hline $\begin{array}{l}\mathrm{SiO}_{2} \\
\mathrm{TiO}_{2} \\
\mathrm{Al}_{2} \mathrm{O}_{3} \\
\mathrm{Cr}_{2} \mathrm{O}_{3} \\
\mathrm{Fe}_{2} \mathrm{O}_{3} \\
\mathrm{MgO} \\
\mathrm{CaO} \\
\mathrm{MnO} \\
\mathrm{FeO} \\
\mathrm{Na}_{2} \mathrm{O} \\
\text { Total }\end{array}$ & $\begin{array}{r}48.07 \\
1.55 \\
4.57 \\
0.00 \\
5.38 \\
13.56 \\
19.98 \\
0.35 \\
7.03 \\
0.37 \\
100.86\end{array}$ & $\begin{array}{r}51.77 \\
0.4 \\
2.17 \\
0.01 \\
3.27 \\
15.49 \\
21.25 \\
0.20 \\
5.61 \\
0.28 \\
100.45\end{array}$ & $\begin{array}{r}52.43 \\
0.35 \\
0.86 \\
0.00 \\
0.00 \\
17.96 \\
6.89 \\
1.08 \\
19.36 \\
0.11 \\
99.04\end{array}$ & $\begin{array}{r}51.02 \\
0.64 \\
1.9 \\
0.01 \\
2.66 \\
14.06 \\
18.55 \\
0.59 \\
10.38 \\
0.35 \\
100.16\end{array}$ & $\begin{array}{r}51.51 \\
0.58 \\
2.29 \\
0.00 \\
1.67 \\
14.45 \\
20.44 \\
0.32 \\
8.51 \\
0.29 \\
100.06\end{array}$ & $\begin{array}{r}45.33 \\
1.95 \\
6.64 \\
0.02 \\
5.99 \\
11.35 \\
19.86 \\
0.46 \\
7.97 \\
0.40 \\
99.97\end{array}$ & $\begin{array}{r}44.82 \\
2.19 \\
6.62 \\
0.00 \\
4.43 \\
9.93 \\
16.76 \\
0.60 \\
13.74 \\
0.44 \\
99.53\end{array}$ & $\begin{array}{r}49.85 \\
0.86 \\
2.52 \\
0.00 \\
4.46 \\
13.23 \\
20.85 \\
0.60 \\
8.26 \\
0.26 \\
100.89\end{array}$ & $\begin{array}{r}50.58 \\
0.53 \\
1.49 \\
0.00 \\
3.03 \\
12.40 \\
18.21 \\
0.79 \\
13.59 \\
0.24 \\
100.86\end{array}$ & $\begin{array}{r}51.15 \\
0.48 \\
1.56 \\
0.03 \\
1.03 \\
14.94 \\
10.86 \\
0.90 \\
19.24 \\
0.19 \\
100.38\end{array}$ & $\begin{array}{r}51.38 \\
0.34 \\
0.89 \\
0.06 \\
0.00 \\
16.49 \\
4.82 \\
1.18 \\
24.22 \\
0.07 \\
99.45\end{array}$ \\
\hline $\begin{array}{l}\mathrm{Si} \\
\mathrm{Ti} \\
\mathrm{Al} \\
\mathrm{Cr} \\
\mathrm{Fe}^{3+} \\
\mathrm{Mg} \\
\mathrm{Ca} \\
\mathrm{Mn} \\
\mathrm{Fe}^{2+} \\
\mathrm{Na} \\
\text { Total }\end{array}$ & $\begin{array}{l}1.787 \\
0.044 \\
0.207 \\
0.000 \\
0.152 \\
0.759 \\
0.795 \\
0.011 \\
0.221 \\
0.028 \\
4.004\end{array}$ & $\begin{array}{l}1.904 \\
0.011 \\
0.098 \\
0.000 \\
0.092 \\
0.857 \\
0.837 \\
0.006 \\
0.175 \\
0.021 \\
4.001\end{array}$ & $\begin{array}{l}1.981 \\
0.010 \\
0.040 \\
0.000 \\
0.000 \\
1.021 \\
0.278 \\
0.035 \\
0.619 \\
0.008 \\
3.992\end{array}$ & $\begin{array}{l}1.911 \\
0.018 \\
0.087 \\
0.000 \\
0.076 \\
0.793 \\
0.744 \\
0.019 \\
0.329 \\
0.026 \\
4.003\end{array}$ & $\begin{array}{l}1.915 \\
0.017 \\
0.104 \\
0.000 \\
0.047 \\
0.809 \\
0.813 \\
0.010 \\
0.268 \\
0.022 \\
4.005\end{array}$ & $\begin{array}{l}1.716 \\
0.056 \\
0.306 \\
0.001 \\
0.173 \\
0.647 \\
0.804 \\
0.015 \\
0.255 \\
0.031 \\
4.004\end{array}$ & $\begin{array}{l}1.728 \\
0.065 \\
0.311 \\
0.000 \\
0.130 \\
0.576 \\
0.691 \\
0.020 \\
0.448 \\
0.034 \\
4.003\end{array}$ & $\begin{array}{l}1.861 \\
0.024 \\
0.115 \\
0.000 \\
0.127 \\
0.744 \\
0.833 \\
0.019 \\
0.261 \\
0.020 \\
4.004\end{array}$ & $\begin{array}{l}1.912 \\
0.015 \\
0.069 \\
0.000 \\
0.087 \\
0.706 \\
0.736 \\
0.026 \\
0.435 \\
0.019 \\
4.005\end{array}$ & $\begin{array}{l}1.937 \\
0.014 \\
0.072 \\
0.001 \\
0.030 \\
0.852 \\
0.440 \\
0.029 \\
0.617 \\
0.015 \\
4.007\end{array}$ & $\begin{array}{l}1.969 \\
0.010 \\
0.042 \\
0.002 \\
0.000 \\
0.951 \\
0.198 \\
0.039 \\
0.786 \\
0.005 \\
4.002\end{array}$ \\
\hline $\begin{array}{l}\text { Wo } \\
\text { En } \\
\text { Fs }\end{array}$ & $\begin{array}{l}41.01 \\
39.14 \\
19.85\end{array}$ & $\begin{array}{l}42.54 \\
43.60 \\
13.86\end{array}$ & $\begin{array}{l}14.25 \\
52.27 \\
33.48\end{array}$ & $\begin{array}{l}37.93 \\
40.43 \\
21.64\end{array}$ & $\begin{array}{l}41.77 \\
41.53 \\
16.70\end{array}$ & $\begin{array}{l}42.47 \\
34.15 \\
23.37\end{array}$ & $\begin{array}{l}37.05 \\
30.88 \\
32.08\end{array}$ & $\begin{array}{l}42.00 \\
37.48 \\
20.52\end{array}$ & $\begin{array}{l}37.01 \\
35.46 \\
27.53\end{array}$ & $\begin{array}{l}22.36 \\
43.29 \\
34.34\end{array}$ & $\begin{array}{l}10.02 \\
48.20 \\
41.78\end{array}$ \\
\hline
\end{tabular}

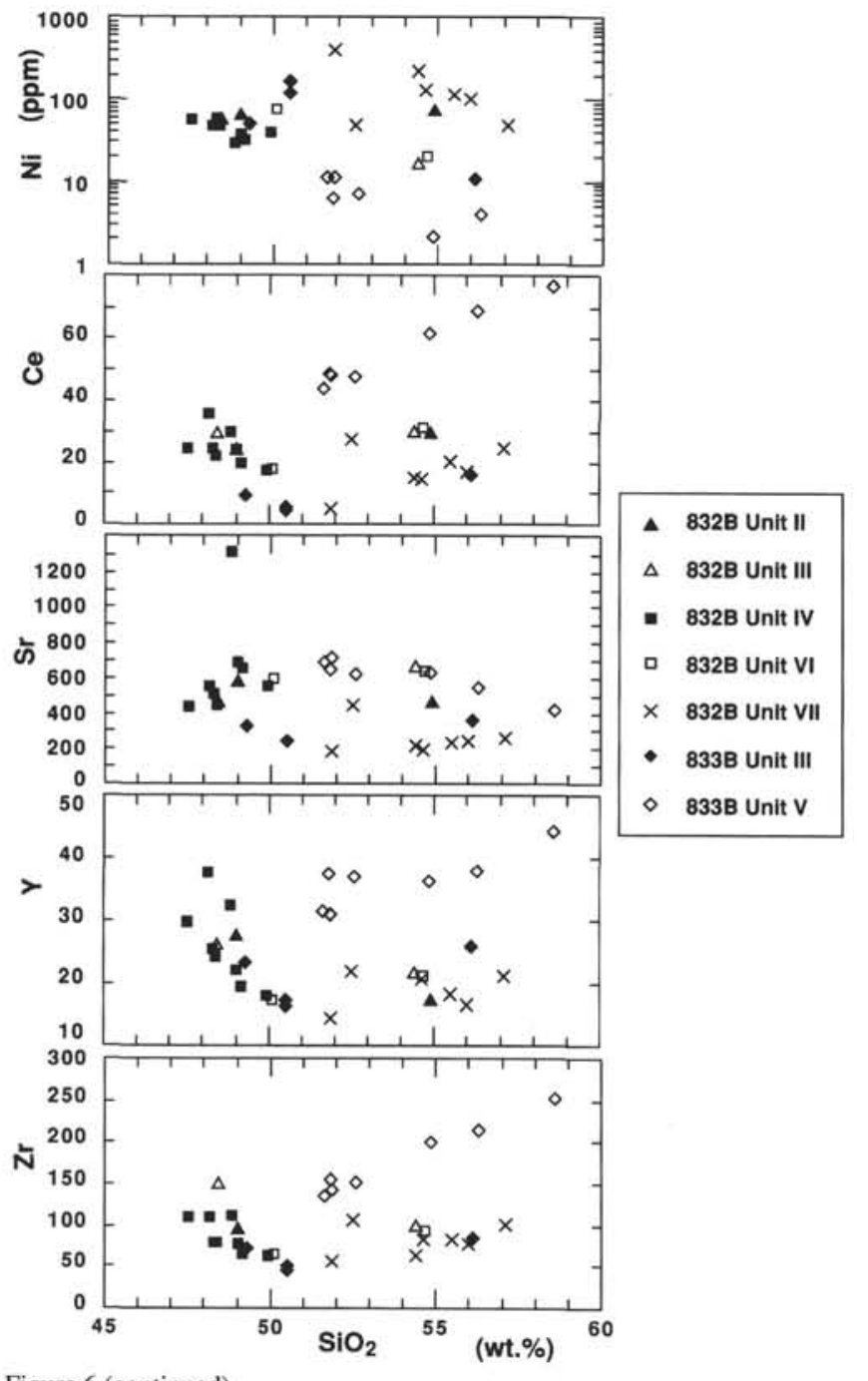

Figure 6 (continued).
Table 4. Representative microprobe analyses (weight \%) and atomic proportions of Fe-Ti oxides from North Aoba Basin lava clasts and sills.

\begin{tabular}{|c|c|c|c|c|c|c|c|}
\hline $\begin{array}{l}\text { Hole: } \\
\text { Core-section: } \\
\text { Interval }(\mathrm{cm}): \\
\text { Point: }\end{array}$ & $\begin{array}{c}832 \mathrm{~B} \\
57 \mathrm{R}-2 \\
127-130 \\
\text { core }\end{array}$ & core & $\begin{array}{c}833 \mathrm{~B} \\
36 \mathrm{R}-1 \\
96-99 \\
\text { core }\end{array}$ & gmass & $\begin{array}{c}833 \mathrm{~B} \\
99 \mathrm{R}-5 \\
71-77 \\
\text { core }\end{array}$ & gmass & core \\
\hline $\begin{array}{l}\mathrm{SiO}_{2} \\
\mathrm{TiO}_{2} \\
\mathrm{Al}_{2} \mathrm{O}_{3} \\
\mathrm{Cr}_{2} \mathrm{O}_{3} \\
\mathrm{Fe}_{2} \mathrm{O}_{3} \\
\mathrm{FeO} \\
\mathrm{MnO} \\
\mathrm{MgO} \\
\mathrm{CaO} \\
\mathrm{NiO} \\
\text { Total }\end{array}$ & $\begin{array}{r}0.11 \\
7.23 \\
4.58 \\
0.27 \\
51.73 \\
35.69 \\
0.45 \\
2.09 \\
0.01 \\
0.00 \\
102.16\end{array}$ & $\begin{array}{r}0.11 \\
10.49 \\
2.65 \\
0.26 \\
46.92 \\
39.54 \\
0.48 \\
1.22 \\
0.02 \\
0.00 \\
101.69\end{array}$ & $\begin{array}{r}0.09 \\
7.34 \\
3.20 \\
0.11 \\
51.72 \\
34.11 \\
0.52 \\
2.32 \\
0.12 \\
0.06 \\
99.59\end{array}$ & $\begin{array}{r}0.11 \\
11.62 \\
1.47 \\
0.00 \\
44.74 \\
39.68 \\
0.60 \\
1.03 \\
0.16 \\
0.00 \\
99.41\end{array}$ & $\begin{array}{r}0.00 \\
10.68 \\
3.97 \\
0.00 \\
44.70 \\
38.05 \\
0.30 \\
2.08 \\
0.00 \\
0.06 \\
99.84\end{array}$ & $\begin{array}{r}0.00 \\
17.41 \\
0.92 \\
0.00 \\
33.66 \\
45.38 \\
0.60 \\
0.60 \\
0.00 \\
0.05 \\
98.62\end{array}$ & $\begin{array}{r}0.00 \\
6.12 \\
5.54 \\
0.00 \\
52.27 \\
31.25 \\
0.24 \\
3.89 \\
0.00 \\
0.00 \\
99.32\end{array}$ \\
\hline \multicolumn{8}{|c|}{$\mathrm{O}=4$} \\
\hline $\begin{array}{l}\mathrm{Si} \\
\mathrm{Ti} \\
\mathrm{Al} \\
\mathrm{Cr} \\
\mathrm{Fe}^{3+} \\
\mathrm{Fe}^{2+} \\
\mathrm{Mn} \\
\mathrm{Mg} \\
\mathrm{Ca} \\
\mathrm{Ni} \\
\text { Total }\end{array}$ & $\begin{array}{l}0.004 \\
0.196 \\
0.194 \\
0.008 \\
1.400 \\
1.073 \\
0.014 \\
0.112 \\
0.000 \\
0.000 \\
3.000\end{array}$ & $\begin{array}{l}0.004 \\
0.289 \\
0.114 \\
0.008 \\
1.293 \\
1.211 \\
0.015 \\
0.067 \\
0.001 \\
0.000 \\
3.000\end{array}$ & $\begin{array}{l}0.003 \\
0.204 \\
0.140 \\
0.003 \\
1.442 \\
1.057 \\
0.016 \\
0.128 \\
0.005 \\
0.002 \\
3.000\end{array}$ & $\begin{array}{l}0.004 \\
0.329 \\
0.065 \\
0.000 \\
1.268 \\
1.250 \\
0.019 \\
0.058 \\
0.007 \\
0.000 \\
3.000\end{array}$ & $\begin{array}{l}0.000 \\
0.295 \\
0.172 \\
0.000 \\
1.237 \\
1.170 \\
0.009 \\
0.114 \\
0.000 \\
0.002 \\
3.000\end{array}$ & $\begin{array}{l}0.000 \\
0.498 \\
0.041 \\
0.000 \\
0.963 \\
1.443 \\
0.019 \\
0.034 \\
0.000 \\
0.002 \\
3.000\end{array}$ & $\begin{array}{l}0.000 \\
0.167 \\
0.237 \\
0.000 \\
1.429 \\
0.949 \\
0.007 \\
0.211 \\
0.000 \\
0.000 \\
3.000\end{array}$ \\
\hline Mol.\%Usp & 20.0 & 29.3 & 20.8 & 33.3 & 29.5 & 49.8 & 16.7 \\
\hline
\end{tabular}

An interesting feature of clast compositions from Units II, III, IV, and VI in Hole 832B is the apparent presence of two subtly different chemical groups, the only significant compositional difference being their K/Rb values. Despite almost identical REE patterns (Fig. 9A), these two compositional groups have clearly different element patterns for the $\mathrm{Sr}$ through $\mathrm{Th}$ section of the variation diagrams shown in Figures 9B and C. Group 1 includes basalts and andesites, and shows broad convex-upward patterns with normalized $\mathrm{Rb}$ values always higher than those for $\mathrm{K} ; \mathrm{K} / \mathrm{Rb}$ values are from $490-570$. In contrast, Group 2 basalts and andesites show flatter patterns from $\mathrm{Sr}$ through $\mathrm{Rb}$ and have normalized $\mathrm{Rb}$ values that are level with or below those for $\mathrm{K} ; \mathrm{K} / \mathrm{Rb}$ values vary from $650-760$. 
Table 5. Major and trace element compositions of volcanic clast and sill samples recovered from North Aoba Basin. Shipboard analyses are from Collot, Greene, Stokking, et al. (1992).

\begin{tabular}{|c|c|c|c|c|c|c|c|c|c|c|c|c|c|c|c|c|}
\hline Hole: & $832 \mathrm{~B}$ & $832 \mathrm{~B}$ & $832 \mathrm{~B}$ & $832 \mathrm{~B}$ & $832 \mathrm{~B}$ & $832 \mathrm{~B}$ & $832 \mathrm{~B}$ & $832 \mathrm{~B}$ & $832 \mathrm{~B}$ & $832 \mathrm{~B}$ & $832 \mathrm{~B}$ & $832 \mathrm{~B}$ & $832 \mathrm{~B}$ & $832 \mathrm{~B}$ & $832 \mathrm{~B}$ & $832 \mathrm{~B}$ \\
\hline Lithostratigraphic unit: & II & II & III & III & IV & IV & IV & IV & IV & IV & IV & IV & VI & VI & VII & VII \\
\hline Core-section: & $28 \mathrm{R}-1$ & $3 \mid R-1$ & $41 \mathrm{R}-1$ & $43 R-3$ & $5 I R-3$ & $51 R-5$ & $54 \mathrm{R}-1$ & $55 \mathrm{R}-4$ & $56 \mathrm{R}-2$ & $57 \mathrm{R}-2$ & $57 \mathrm{R}-2$ & $57 R-4$ & $78 \mathrm{R}-1$ & $78 R-1$ & $88 \mathrm{R}-1$ & 91R-CC \\
\hline Interval $(\mathrm{cm})$ : & $97-99$ & $129-132$ & $17-21$ & $19-21$ & $2-4$ & $8-11$ & $119-122$ & $128-131$ & $46-48$ & $62-64$ & $115-118$ & $129-132$ & $0-3$ & $8-10$ & $90-95$ & \\
\hline Depth (mbsf): & 405.87 & 434.49 & 529.37 & 551.69 & 628.68 & 631.67 & 655.89 & 670.18 & 674.96 & 684.76 & 685.29 & 688.29 & 885.00 & 885.08 & 982.00 & 1019.10 \\
\hline Lab: & Ferrara & Tohoku & Ship & Tohoku & Tohoku & Tohoku & Tohoku & Tohoku & Tohoku & Tohoku & Tohoku & Tohoku & Tohoku & Tohoku & Tohoku & Tohoku \\
\hline $\mathrm{SiO}_{2}$ & 54.89 & 49.02 & 48.45 & 54.41 & 48.86 & 47.55 & 48.37 & 49.03 & 48.29 & 49.17 & 49.93 & 48.16 & 50.11 & 54.65 & 56.00 & 54.61 \\
\hline $\mathrm{TiO}_{2}^{2}$ & 0.77 & 1.27 & 1.46 & 0.76 & 1.67 & 1.59 & 1.12 & 0.92 & 1.22 & 0.89 & 0.81 & 1.54 & 0.76 & 0.69 & 0.61 & 0.77 \\
\hline $\mathrm{Al}_{2} \mathrm{O}_{3}$ & 16.09 & 14.51 & 14.52 & 17.55 & 15.16 & 14.93 & 14.52 & 17.34 & 14.06 & 15.84 & 15.19 & 15.55 & 13.42 & 17.42 & 14.95 & 14.85 \\
\hline $\mathrm{Fe}_{2} \mathrm{O}_{3}$ & 1.35 & 1.65 & 1.54 & 1.17 & 1.52 & 1.63 & 1.62 & 1.49 & 1.57 & 1.65 & 1.58 & 1.71 & 1.52 & 1.07 & 1.16 & 1.19 \\
\hline $\mathrm{FeO}$ & 8.07 & 9.88 & 9.23 & 7.02 & 9.09 & 9.76 & 9.74 & 8.94 & 9.44 & 9.88 & 9.48 & 10.26 & 9.15 & 6.40 & 6.93 & 7.14 \\
\hline $\mathrm{MnO}$ & 0.15 & 0.21 & 0.19 & 0.16 & 0.18 & 0.20 & 0.20 & 0.19 & 0.21 & 0.21 & 0.17 & 0.19 & 0.19 & 0.16 & 0.16 & 0.16 \\
\hline $\mathrm{MgO}$ & 8.59 & 7.51 & 7.51 & 4.42 & 6.05 & 8.12 & 7.83 & 6.15 & 8.83 & 6.64 & 6.88 & 6.03 & 8.97 & 4.97 & 7.63 & 8.02 \\
\hline $\mathrm{CaO}$ & 6.31 & 12.32 & 13.78 & 9.07 & 13.18 & 12.50 & 13.35 & 12.13 & 12.49 & 11.60 & 11.86 & 11.69 & 12.06 & 9.37 & 9.15 & 9.64 \\
\hline $\mathrm{Na}_{2} \mathrm{O}$ & 2.71 & 2.64 & 2.23 & 3.60 & 2.81 & 2.74 & 2.39 & 2.94 & 2.49 & 3.02 & 2.91 & 3.04 & 2.61 & 3.56 & 2.64 & 2.92 \\
\hline $\mathrm{K}_{2} \mathrm{O}$ & 0.81 & 0.76 & 0.81 & 1.60 & 1.17 & 0.73 & 0.63 & 0.64 & 1.16 & 0.92 & 1.01 & 1.52 & 1.01 & 1.48 & 0.67 & 0.61 \\
\hline $\mathrm{P}_{2}^{2} \mathrm{O}_{5}$ & 0.24 & 0.24 & 0.29 & 0.25 & 0.30 & 0.26 & 0.22 & 0.23 & 0.21 & 0.18 & 0.19 & 0.32 & 0.19 & 0.23 & 0.09 & 0.10 \\
\hline $\mathrm{FeO}^{*}$ & 9.28 & 11.36 & 10.62 & 8.08 & 10.46 & 11.22 & 11.20 & 10.28 & 10.86 & 11.37 & 10.90 & 11.80 & 10.52 & 7.36 & 7.97 & 8.21 \\
\hline $\mathrm{Ni}$ & 70 & 61 & 55 & 16 & 29 & 57 & 48 & 37 & 60 & 32 & 40 & 48 & 77 & 20 & 100 & 131 \\
\hline $\mathrm{Cr}$ & 357 & 219 & 181 & 29 & 129 & 188 & 195 & 80 & 213 & 63 & 104 & 69 & 336 & 72 & 463 & 517 \\
\hline V & 295 & 316 & 349 & 271 & 369 & 346 & 351 & 358 & 324 & 378 & 302 & 353 & 319 & 262 & 239 & 230 \\
\hline $\mathrm{Zr}$ & - & 95 & 148 & 97 & 111 & 110 & 79 & 78 & 79 & 65 & 63 & 110 & 64 & 93 & 79 & 83 \\
\hline $\mathrm{Ce}$ & 29 & 24 & 29 & 29 & 30 & 25 & 22 & 24 & 25 & 20 & 17 & 36 & 18 & 31 & 17 & 14 \\
\hline $\mathrm{Nb}$ & - & 6 & 9 & 3 & 9 & 11 & 4 & 2 & 5 & 1 & 2 & 8 & 2 & 3 & 6 & 5 \\
\hline $\mathrm{Y}$ & 17 & 27 & 26 & 21 & 32 & 30 & 24 & 22 & 25 & 20 & 18 & 38 & 17 & 21 & 17 & 21 \\
\hline Th & 4 & 2 & - & 3 & 2 & 3 & 2 & 3 & 1 & 2 & 2 & 3 & 1 & 3 & 2 & 1 \\
\hline $\mathrm{Sr}$ & 457 & 572 & 457 & 654 & 1314 & 440 & 447 & 688 & 516 & 657 & 557 & 553 & 603 & 640 & 244 & 191 \\
\hline $\mathrm{Rb}$ & 10 & 6 & 8 & 28 & 13 & 8 & 8 & 4 & 17 & 6 & 13 & 31 & 17 & 25 & 14 & 13 \\
\hline $\mathrm{Ba}$ & 206 & 148 & 209 & 327 & 193 & 147 & 185 & 291 & 217 & 250 & 260 & 193 & 202 & 335 & 174 & 146 \\
\hline $\mathrm{Pb}$ & - & 3 & - & 4 & 3 & 4 & 4 & 5 & 4 & 5 & 4 & 4 & 5 & 5 & 3 & 3 \\
\hline $\mathrm{Cu}$ & - & 118 & 94 & 87 & 161 & 145 & 153 & 132 & 74 & 44 & 61 & 78 & 151 & 125 & 86 & 88 \\
\hline $\mathrm{Zn}$ & 74 & 89 & 84 & 64 & 79 & 95 & 88 & 85 & 82 & 86 & 74 & 118 & 83 & 59 & 71 & 74 \\
\hline $\mathrm{Ga}$ & - & 18 & - & 19 & 18 & 20 & 19 & 20 & 18 & 19 & 20 & 20 & 17 & 20 & 16 & 17 \\
\hline
\end{tabular}

Table 5 (continued).

\begin{tabular}{|c|c|c|c|c|c|c|c|c|c|c|c|c|c|c|c|c|}
\hline Hole: & $832 \mathrm{~B}$ & $832 \mathrm{~B}$ & $832 \mathrm{~B}$ & $832 \mathrm{~B}$ & $832 \mathrm{~B}$ & $832 \mathrm{~B}$ & $833 B$ & $833 \mathrm{~B}$ & $833 \mathrm{~B}$ & $833 \mathrm{~B}$ & 833B & 833B & $833 \mathrm{~B}$ & 833B & $833 \mathrm{~B}$ & 833B \\
\hline Lithostratigraphic unit: & VII & VII & VII & VII & VII & VII & III & III & III & III & V & V & V & V & $\mathrm{v}$ & $\mathrm{v}$ \\
\hline Core-section: & $94 \mathrm{R}-1$ & $94 \mathrm{R}-2$ & $99 \mathrm{R}-3$ & $100 \mathrm{R}-3$ & $100 R-4$ & $34 \mathrm{R}-\mathrm{CC}$ & $35 \mathrm{R}-33$ & $6 \mathrm{R}-1$ & $37 \mathrm{R}-1$ & $81 \mathrm{R}-2$ & $84 \mathrm{R}-1$ & $91 \mathrm{R}-2$ & $93 R-1$ & $94 \mathrm{R}-2$ & $93 R-3$ & $98 \mathrm{R}-1$ \\
\hline Interval $(\mathrm{cm})$ : & $34-37$ & $23-26$ & $53-57$ & $143-146$ & $3-7$ & $1-4$ & $135-137$ & $94-96$ & $7-9$ & $93-96$ & $48-51$ & $81-85$ & $53-56$ & $92-94$ & $46-49$ & $114-118$ \\
\hline Depth (mbsf): & 1039.34 & 1040.70 & 1090.83 & 1101.43 & 1101.54 & 404.21 & 409.25 & 415.44 & 424.27 & 830.43 & 851.68 & 916.51 & 934.13 & 945.72 & 966.06 & 983.04 \\
\hline Lab: & Tohoku & Tohoku & Tohoku & Tohoku & Tohoku & Ferrara & Tohoku & Tohoku & Tohoku & Tohoku & Tohoku & Tohoku & Tohoku & Tohoku & Tohoku & Tohoku \\
\hline $\mathrm{SiO}_{2}$ & 55.50 & 51.85 & 52.48 & 54.40 & 57.13 & 49.27 & 50.52 & 56.13 & 50.51 & 52.57 & 51.80 & 51.66 & 51.87 & 54.84 & 56.30 & 58.58 \\
\hline $\mathrm{TiO}_{2}$ & 0.64 & 0.51 & 0.81 & 0.61 & 0.73 & 1.01 & 0.63 & 0.78 & 0.58 & 1.15 & 1.18 & 1.15 & 1.17 & 1.06 & 1.06 & 1.05 \\
\hline $\mathrm{Al}_{2} \mathrm{O}_{3}$ & 15.10 & 12.66 & 18.04 & 14.34 & 16.83 & 17.65 & 14.53 & 17.44 & 13.72 & 17.16 & 17.07 & 16.11 & 16.79 & 16.11 & 15.73 & 15.29 \\
\hline $\mathrm{Fe}_{2}^{2} \mathrm{O}_{3}$ & 1.20 & 1.24 & 1.15 & 1.16 & 1.07 & 1.46 & 1.31 & 1.20 & 1.34 & 1.54 & 1.56 & 1.65 & 1.56 & 1.45 & 1.36 & 1.28 \\
\hline $\mathrm{FeO}^{3}$ & 7.22 & 7.41 & 6.93 & 6.99 & 6.45 & 8.77 & 7.84 & 7.19 & 8.04 & 9.25 & 9.38 & 9.93 & 9.36 & 8.73 & 8.19 & 7.67 \\
\hline $\mathrm{MnO}$ & 0.16 & 0.25 & 0.16 & 0.20 & 0.15 & 0.19 & 0.20 & 0.19 & 0.18 & 0.22 & 0.23 & 0.21 & 0.19 & 0.23 & 0.19 & 0.19 \\
\hline $\mathrm{MgO}$ & 7.78 & 13.01 & 5.95 & 9.85 & 5.15 & 6.63 & 9.58 & 4.05 & 10.38 & 3.31 & 3.64 & 4.30 & 3.78 & 3.18 & 2.84 & 2.34 \\
\hline $\mathrm{CaO}$ & 8.72 & 11.00 & 9.86 & 9.63 & 8.11 & 11.86 & 13.30 & 8.20 & 12.84 & 8.81 & 9.02 & 8.58 & 8.58 & 7.03 & 6.24 & 4.33 \\
\hline $\mathrm{Na}_{2} \mathrm{O}$ & 2.85 & 1.85 & 3.41 & 2.20 & 3.25 & 2.69 & 1.89 & 4.02 & 2.09 & 3.94 & 3.75 & 3.75 & 3.91 & 4.16 & 4.24 & 4.36 \\
\hline $\mathrm{K}_{2} \mathrm{O}$ & 0.73 & 0.13 & 0.86 & 0.45 & 0.99 & 0.31 & 0.11 & 0.65 & 0.20 & 1.57 & 1.88 & 2.15 & 2.27 & 2.62 & 3.23 & 4.16 \\
\hline $\mathrm{P}_{2} \mathrm{O}_{5}{ }^{*}$ & 0.11 & 0.10 & 0.35 & 0.15 & 0.13 & 0.14 & 0.09 & 0.16 & 0.11 & 0.46 & 0.48 & 0.50 & 0.52 & 0.60 & 0.61 & 0.76 \\
\hline $\mathrm{FeO}^{*}$ & 8.30 & 8.52 & 7.96 & 8.03 & 7.41 & 10.09 & 9.02 & 8.26 & 9.25 & 10.64 & 10.79 & 11.42 & 10.77 & 10.03 & 9.41 & 8.82 \\
\hline $\mathrm{Ni}$ & 116 & 402 & 48 & 227 & 48 & 51 & 123 & 11 & 166 & 7 & 6 & 11 & 11 & 2 & 4 & BDL \\
\hline $\mathrm{Cr}$ & 295 & 852 & 119 & 487 & 117 & 120 & 371 & 30 & 552 & 9 & 8 & 9 & 11 & I & 1 & BDL \\
\hline V & 239 & 212 & 310 & 206 & 233 & 352 & 300 & 230 & 288 & 291 & 307 & 362 & 408 & 276 & 232 & 157 \\
\hline $\mathrm{Zr}$ & 83 & 57 & 107 & 63 & 102 & 73 & 50 & 85 & 45 & 152 & 156 & 136 & 143 & 201 & 215 & 254 \\
\hline $\mathrm{Ce}$ & 20 & 5 & 28 & 15 & 25 & 9 & 5 & 16 & 4 & 48 & 49 & 44 & 48 & 62 & 69 & 77 \\
\hline $\mathrm{Nb}$ & 6 & 3 & 8 & 5 & 7 & 5 & 3 & 3 & 1 & 7 & 8 & 5 & 6 & 7 & 8 & 9 \\
\hline $\mathrm{Y}$ & 18 & 14 & 22 & - & 21 & 23 & 17 & 26 & 16 & 37 & 37 & 32 & 31 & 36 & 38 & 45 \\
\hline Th & 2 & 2 & 3 & 2 & 3 & 1 & 1 & 1 & 1 & 3 & 4 & 3 & 3 & 4 & 4 & 5 \\
\hline $\mathrm{Sr}$ & 236 & 182 & 451 & 221 & 264 & 330 & 248 & 364 & 247 & 626 & 646 & 694 & 715 & 635 & 547 & 426 \\
\hline $\mathrm{Rb}$ & 17 & 1 & 12 & 10 & 22 & 1 & 1 & 9 & 0 & 26 & 18 & 30 & 37 & 29 & 55 & 77 \\
\hline $\mathrm{Ba}$ & 198 & 47 & 207 & 164 & 260 & 130 & 69 & 280 & 138 & 212 & 217 & 236 & 233 & 283 & 293 & 343 \\
\hline $\mathrm{Pb}$ & 4 & 4 & 4 & - & 5 & 4 & 3 & 3 & 2 & 9 & 8 & 8 & 9 & 11 & 7 & 7 \\
\hline $\mathrm{Cu}$ & 108 & 87 & 98 & - & 114 & 162 & 94 & 120 & 92 & 348 & 374 & 279 & 314 & 318 & 307 & 161 \\
\hline $\mathrm{Zn}$ & 70 & 65 & 69 & 79 & 66 & 79 & 74 & 79 & 66 & 111 & 110 & 92 & 113 & 116 & 90 & 90 \\
\hline $\mathrm{Ga}$ & 16 & 14 & 15 & - & 17 & 19 & 15 & 19 & 15 & 22 & 21 & 21 & 22 & 21 & 21 & 19 \\
\hline
\end{tabular}

This unusual coexistence of two strikingly similar compositional groups of lavas wherein the only differences lie in their respective $\mathrm{K}$ and $\mathrm{Rb}$ contents might suggest that this feature is alteration-related, since both $\mathrm{K}$ and $\mathrm{Rb}$ are readily mobilized during low-temperature alteration and burial metamorphism. However, as emphasized further on, the existence of these same two compositional groups is recorded among very fresh, modern lavas from islands in the central part of the New Hebrides Island Arc, probably precluding an alteration origin for the differences in $\mathrm{K}$ and $\mathrm{Rb}$ contents between these two groups.

\section{Hole $833 B$}

Igneous rocks in this hole include volcanic clasts in lithostratigraphic Unit III, and the evolved basaltic to andesitic sill complex in Unit V. Basaltic clasts in Unit III fall at the low- $\mathrm{TiO}_{2}$, low-FeO" end of the spectrum of basalt compositions from Hole 832B (Fig. 6). However Unit III basalts have lower $\mathrm{K}_{2} \mathrm{O}, \mathrm{P}_{2} \mathrm{O}_{5}, \mathrm{Rb}, \mathrm{Ba}$, and $\mathrm{Ce}$ contents than any Hole $832 \mathrm{~B}$ basalts from Units II to VI and have almost flat REE patterns (Fig. 10A) and element variation patterns 
Table 6. Rare earth element compositions of volcanic clast and sill samples recovered from North Aoba Basin Holes 832B and 833B.

\begin{tabular}{|c|c|c|c|c|c|c|c|c|c|c|c|c|c|c|}
\hline Hole: & $832 \mathrm{~B}$ & $832 \mathrm{~B}$ & $832 \mathrm{~B}$ & $832 B$ & $832 \mathrm{~B}$ & $833 \mathrm{~B}$ & $833 \mathrm{~B}$ & $833 \mathrm{~B}$ & $833 \mathrm{~B}$ & $833 \mathrm{~B}$ & $833 B$ & $833 \mathrm{~B}$ & $833 \mathrm{~B}$ & $833 \mathrm{~B}$ \\
\hline Core-section: & $51 R-3$ & $56 \mathrm{R}-2$ & $78 \mathrm{R}-1$ & $94 \mathrm{R}-1$ & $100 \mathrm{R}-4$ & $36 \mathrm{R}-1$ & $37 \mathrm{R}-1$ & $81 \mathrm{R}-2$ & $81 R-3$ & $82 \mathrm{R}-2$ & $91 \mathrm{R}-2$ & $94 \mathrm{R}-2$ & $96 \mathrm{R}-3$ & $98 \mathrm{R}-1$ \\
\hline Interval $(\mathrm{cm})$ : & $2-4$ & $46-48$ & $0-3$ & $34-37$ & $3-7$ & $94-96$ & $7-9$ & $93-96$ & $1-4$ & $35-37$ & $81-85$ & $92-94$ & $46-49$ & $114-118$ \\
\hline Depth (mbsf): & 628.68 & 674.96 & 885.00 & 1039.34 & 1101.54 & 415.44 & 424.27 & 830.43 & 830.90 & 835.85 & 916.51 & 945.72 & 966.06 & 983.04 \\
\hline $\mathrm{Y}$ & 26.9 & 22.2 & 14.8 & 14.9 & 17.5 & 22.7 & 14.3 & 31.0 & 31.7 & 27.7 & 26.1 & 30.3 & 28.3 & 37.0 \\
\hline $\mathrm{La}$ & 11.7 & 8.2 & 9.1 & 8.0 & 9.9 & 4.4 & 3.5 & 19.2 & 19.7 & 17.6 & 19.8 & 25.4 & 24.0 & 32.7 \\
\hline $\mathrm{Ce}$ & 26.0 & 20.0 & 21.5 & 15.4 & 18.6 & 12.5 & 7.3 & 42.5 & 44.0 & 39.8 & 42.5 & 55.4 & 53.7 & 72.3 \\
\hline $\mathrm{Nd}$ & 17.9 & 13.0 & 13.1 & 7.4 & 9.3 & 8.2 & 4.4 & 25.8 & 26.7 & 23.0 & 26.4 & 33.7 & 31.9 & 44.3 \\
\hline $\mathrm{Sm}$ & 5.49 & 4.27 & 3.94 & 2.39 & 2.84 & 3.10 & 2.06 & 7.30 & 7.50 & 6.48 & 7.21 & 8.80 & 8.51 & 11.30 \\
\hline $\mathrm{Eu}$ & 1.60 & 1.18 & 1.06 & 0.67 & 0.82 & 0.95 & 0.59 & 1.79 & 1.83 & 1.57 & 1.82 & 1.98 & 1.92 & 2.37 \\
\hline Gd & 5.04 & 4.06 & 3.16 & 2.50 & 2.94 & 3.56 & 2.19 & 6.22 & 6.66 & 5.84 & 5.31 & 7.06 & 6.91 & 8.24 \\
\hline Dy & 5.16 & 4.03 & 2.86 & 2.53 & 3.08 & 4.01 & 2.45 & 5.70 & 5.96 & 5.31 & 4.83 & 5.71 & 5.69 & 6.90 \\
\hline $\mathrm{Er}$ & 3.02 & 2.50 & 1.65 & 1.58 & 1.90 & 2.59 & 1.47 & 3.60 & 3.61 & 3.17 & 2.92 & 3.48 & 3.38 & 4.12 \\
\hline $\mathrm{Yb}$ & 2.71 & 2.27 & 1.52 & 1.56 & 1.88 & 2.63 & 1.49 & 3.24 & 3.37 & 2.96 & 2.70 & 3.21 & 3.11 & 3.86 \\
\hline $\mathrm{Lu}$ & 0.39 & 0.35 & 0.25 & 0.25 & 0.29 & 0.41 & 0.23 & 0.62 & 0.53 & 0.43 & 0.40 & 0.37 & 0.47 & 0.54 \\
\hline
\end{tabular}
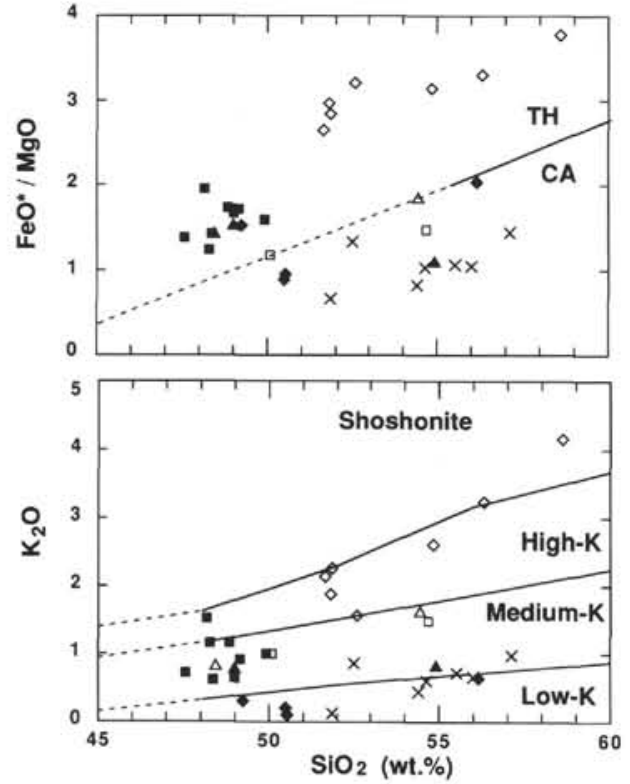

Figure 7. Top: $\mathrm{SiO}_{2}$ vs. $\mathrm{FeO}^{*} / \mathrm{MgO}$ for Holes $832 \mathrm{~B}$ and 833B igneous rocks, showing the tholeiite-calc-alkaline divide suggested by Miyashiro (1974). Symbols as for Figure 6. Bottom: $\mathrm{SiO}_{2}-\mathrm{K}_{2} \mathrm{O}$ diagram showing classification divisions according to Gill (1981). Symbols as for Figure 6.

(Fig. 10B), quite unlike the LREE-enriched patterns of clasts from all units in Hole 832B.

As discussed above, major element considerations suggest that the sill complex includes an essentially comagmatic suite of evolved high-K to shoshonitic basalts and andesites with higher $\mathrm{FeO}^{*}$ and lower $\mathrm{MgO}$ contents at any $\mathrm{SiO}_{2}$ level than the andesitic rocks in Units II through VI in Hole 832B and also the andesite in Unit III in Hole 833B. Sill HFSE contents are significantly higher than those for any drilled lava clasts at any given $\mathrm{SiO}_{2}$ content (Fig. 6). The comagmatic nature of the sill complex is supported by the parallel REE patterns (Fig. 10A) and element variation patterns (Fig. 10B) of the analyzed basalts and andesites, and the fact that the most fractionated andesitic sample has a distinct negative Eu anomaly, reflecting significant prior plagioclase crystallization. Sill REE patterns are strongly LREE-enriched, with sloping HREE, and although quite parallel patterns are shown by some of the Hole 832B clasts (e.g., from Unit VI; see Fig. 8A), other major and trace element considerations firmly preclude any petrogenetic relationships between these clasts and the sill magmas.
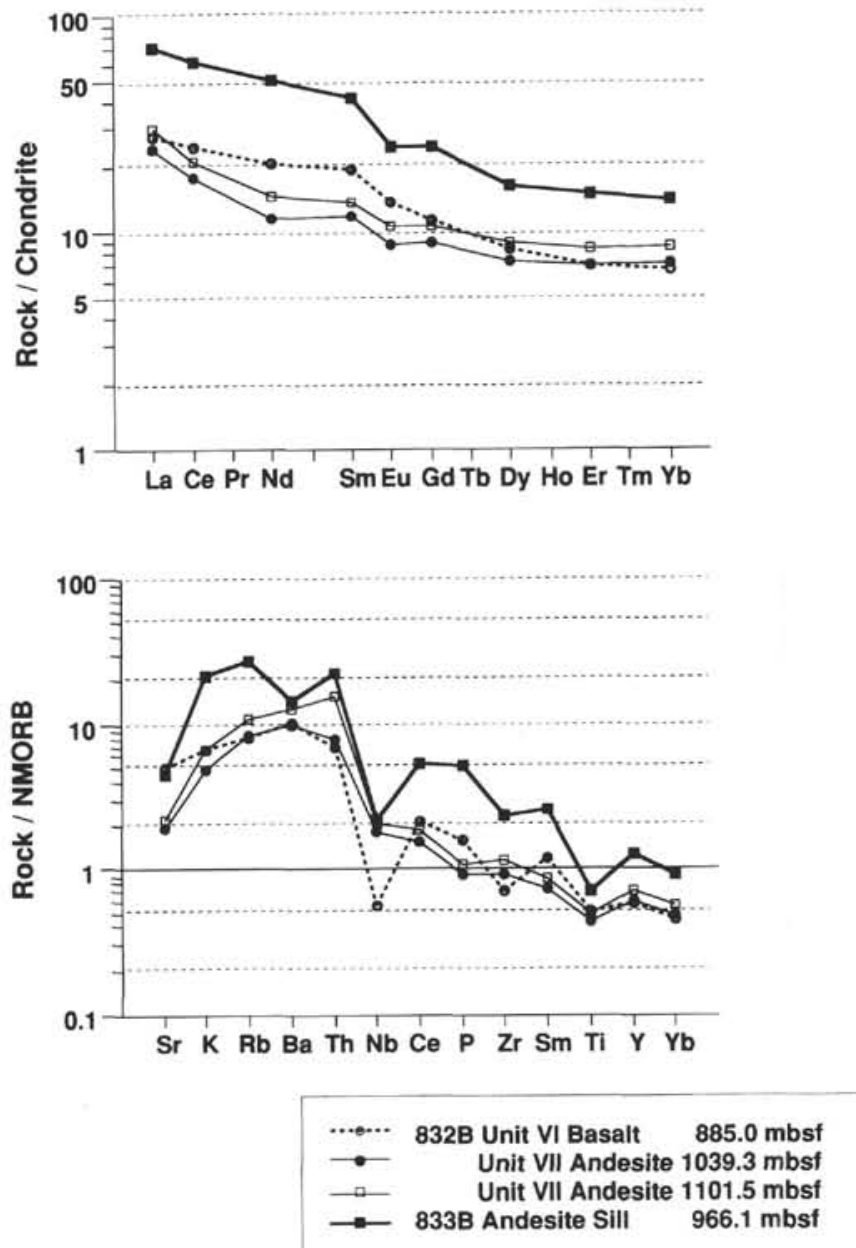

Figure 8. Chondrite-normalized REE patterns and NMORB-normalized element variation patterns for calc-alkaline medium- to low- $\mathrm{K}$ volcanic clasts from Hole 832B lithostratigraphic Unit VII. Shown for comparison are typical REE patterns for a Hole 833B basaltic sill, and a basaltic clast in Late Miocene Unit VI from Hole 832B. Normalizing values for REE from Nakamura (1974) and for NMORB-normalized element variation diagrams from Pearce (1983).

\section{Summary of Compositional-stratigraphic Relationships}

We can distinguish on the basis of compositional characteristics four major magma suites in Holes 832B and 833B: 

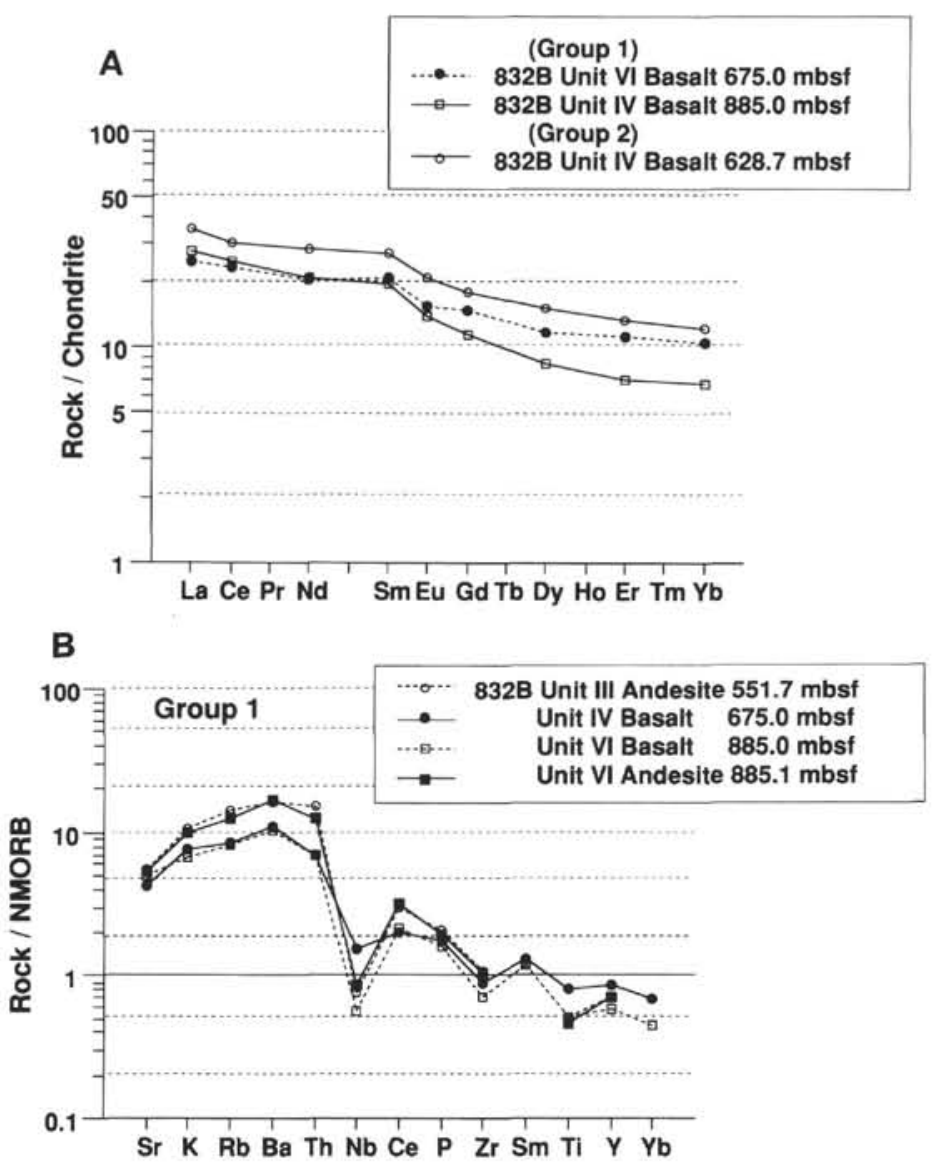

Figure 9. A. Chondrite-normalized REE patterns for medium- to high-K volcanic clasts from Hole 832B lithostratigraphic Units VI and IV, showing the virtually identical patterns for basalts with around $7 \% \mathrm{MgO}$ from compositional subgroups identified. B. NMORB-normalized element variation patterns for medium- to high-K volcanic clasts from Hole 832B lithostratigraphic Units III, IV, and VI, compositional Group 1, showing the relative $\mathrm{K}-\mathrm{Rb}$ enrichment that characterizes this group. C. NMORB-normalized element variation patterns for Group 2 medium- to high-K volcanic clasts from Hole 832B lithostratigraphic Units II, III, IV, and VI, showing the relative $\mathrm{K}-\mathrm{Rb}$ depletion that characterizes this group relative to Group 1.

1. Clearly the oldest suite is represented by the low-to medium-K calc-alkaline basaltic to andesitic clasts in lithostratigraphic Unit VII in Hole 832B. One clast from this suite yielded a K-Ar date of $5.66 \mathrm{Ma}$ (Rex, this volume), although the biostratigraphic age is at least earliest middle Miocene in the upper part of the unit (Perembo, this volume), implying that the K-Ar age may be too young due to incipient alteration and Ar loss.

2. The most abundantly represented suite includes basaltic and andesitic clasts in lithostratigraphic Units VI, IV, III, and II in Hole $832 \mathrm{~B}$. At $6 \%-8 \% \mathrm{MgO}$, this suite shows a strong inverse correlation of HFSE and large ion lithophile element (LILE) contents with $\mathrm{SiO}_{2}$ contents, suggesting that it includes fractionation products of a series of parental magmas produced, as we hypothesize, by varying degrees of partial melting (possibly corresponding to varying pressures of melting) of an essentially similar source. Two subtly different compositional groups exist, differing only in their $\mathrm{K} / \mathrm{Rb}$ values. Units II, III, and IV are Late Pliocene-Pleistocene in age, whereas Unit VI is late Miocene.

3. Late Pliocene lithostratigraphic Unit III in Hole 833B contains lava clasts belonging to a low-K basaltic to andesitic suite that has virtually flat REE patterns.
4. The sill complex in Hole 833B contains high-K to shoshonitic basalts and andesites that are strongly enriched in HFSE and LILE relative to the other suites. Two samples have been $\mathrm{K}-\mathrm{Ar}$ dated at 3.65 and $3.30 \mathrm{Ma}$.

\section{Correlation with Lava Suites from Islands around the North Aoba Basin}

Surrounding the NAB are the Western Belt island of Santo, the Eastern Belt island of Maewo, and the Central Chain active volcanoes of Aoba to the south, Merelava to the northeast, and Santa Maria to the north. In this section, we attempt to correlate the drilled lavas and sills with lava suites from these adjacent islands.

Least well known of the lava suites from these islands are those from the Western Belt; little trace element data are available, but it is well-established that calc-alkaline lavas and dioritic intrusives, often hornblendebearing, are common on both Espiritu Santo and the Torres islands of the Western Belt (Macfarlane et al., 1988). Western Belt magmatism, the oldest recorded in the New Hebrides Island Arc, extended from Late Oligocene ( $25 \mathrm{Ma}$ ) to mid middle Miocene (14 Ma). Although no useful comparative data are available, the calc-alkaline nature and minimum 


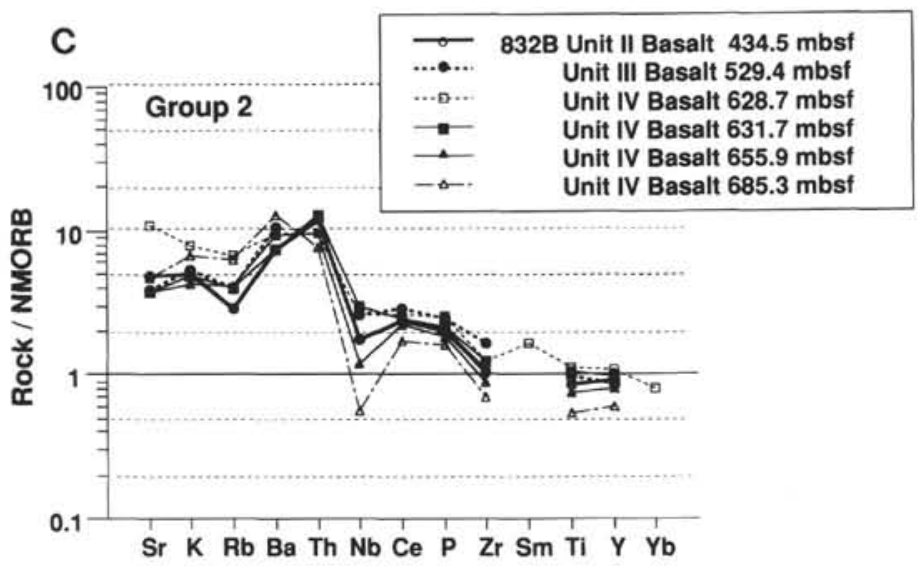

Figure 9 (continued).

middle Miocene age of the Unit VII clasts in Hole 832B all suggest that these were derived from Espiritu Santo Island.

The Eastern Belt islands of Maewo and Pentecost contain extensive late Miocene basaltic and andesitic lavas that erupted mainly between 7 and $4 \mathrm{Ma}$.

Carney (1986) analyzed 17 samples from the Maewo Group and most are medium- and high-K porphyritic basalts and basaltic andesites. No REE data are currently available for these rocks. The Pentecost Group on Pentecost Island, of similar age, is also dominated by basalts and andesites. Largely unpublished data (Johnson et al., 1988; Gorton, 1974 ) indicate that these lavas are mainly medium-K compositions with typically rather flat REE patterns. Neither of these groups is convincingly similar compositionally to the low-K lava clasts from Hole 833B lithostratigraphic Unit III.

Hole 833B lithostratigraphic Unit III lava clasts are, however, strikingly similar petrographically and compositionally to lavas from Merelava volcano, some $75 \mathrm{~km}$ north-northeast of Hole 833B. Merelava is a young stratovolcano astride the western rim of the juvenile Northern (Jean Charcot) Trough that is currently splitting the backarc side of the northern section of the New Hebrides Island Arc (Charvis and Pelletier, 1989). Merelava is dominated by low-K basalts (Barsdell, 1988), with very low HFSE contents (only $40 \mathrm{ppm} \mathrm{Zr}$ at $5 \% \mathrm{MgO}$ ) and flat REE patterns (Figs. 11A and B). The XRF-measured Th and $\mathrm{Nb}$ abundances in Unit III are close to the detection limit for this technique, and actual values are probably lower than the measured values, enhancing the similarity of the Unit III and evolved Merelava basalts in Figure 11B. However, the Unit III andesite has somewhat higher $\mathrm{P}, \mathrm{Zr}$, and Y contents than the evolved Merelava basalts at $4 \%-5 \% \mathrm{MgO}$, and is obviously not strictly comagmatic with them. Despite this difference in HFSE contents, the pronounced compositional similarity of the Hole 833B Unit III andesites and the evolved basalts from Merelava is persuasive.

This suggests that the late Pliocene lithostratigraphic Unit III clasts are derived either from an early phase of Merelava magmatism, or perhaps more likely, they may be derived from a more proximal, compositionally very similar volcano in a similar tectonic setting to Merelava along the eastern margin of the Central Chain. The southern limit of the Northern Trough is very poorly known, and it may extend further south than Merelava towards Maewo Island, at the northern end of the uplifted Eastern belt ridge. Uplift of the Maewo-Pentecost Ridge since the Pliocene has clearly disrupted the development of the juvenile backarc trough in this part of the arc (Fig. 1). These Unit III lava breccias may have been emplaced into the $\mathrm{NAB}$ as mass flows from the east or northeast during the collision of this part of the arc with the d'Entrecasteaux Zone $\sim 2 \mathrm{Ma}$.

Aoba Island, bordering the south end of the NAB, is a young shield volcano $15 \mathrm{~km}$ across, with abundant picritic basalts, ankaramites, olivine + clinopyroxene-phyric basalts and subordinate plagioclasephyric basalts (Gorton, 1977; Eggins, 1993). A detailed petrological-
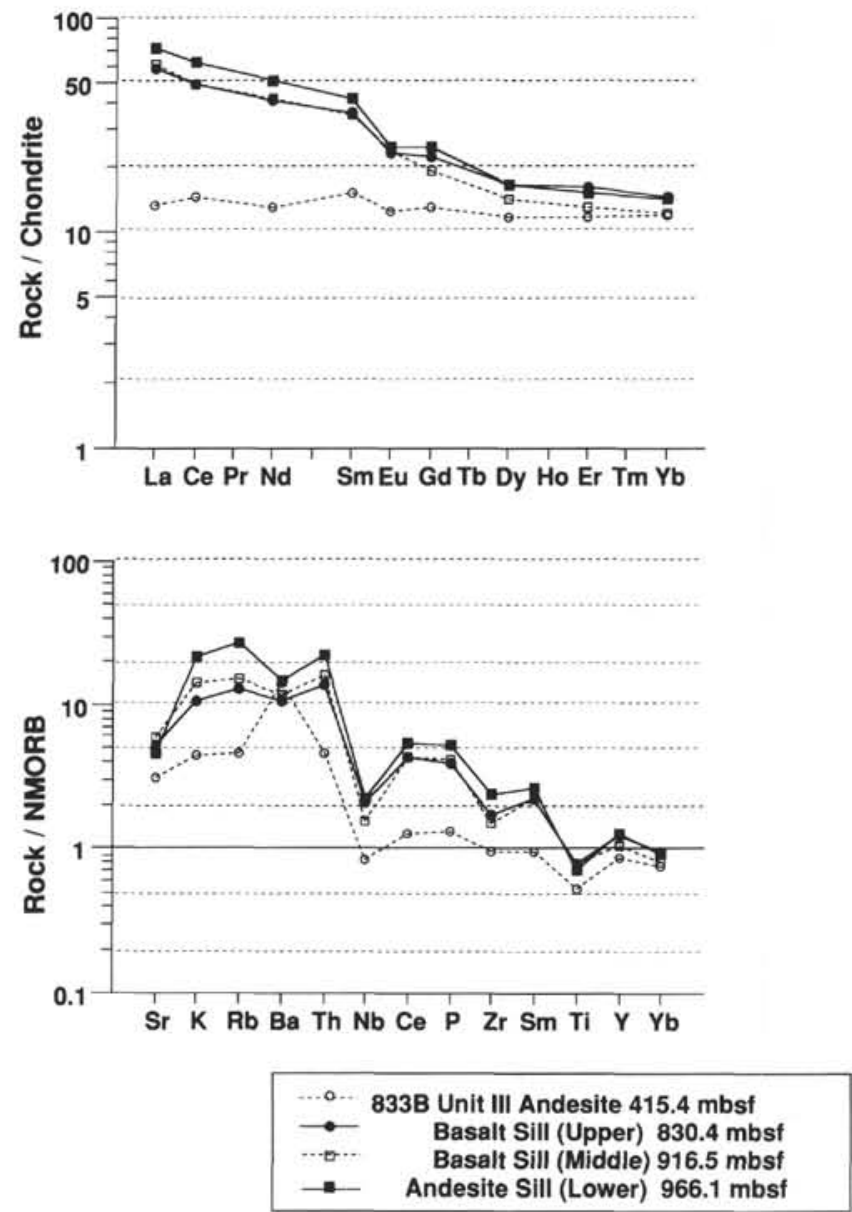

Figure 10. Top: Chondrite-normalized REE patterns for low-K volcanic clasts from Hole 833B lithostratigraphic Units III and for evolved basaltic to andesitic sills from Unit V. Bottom: NMORB-normalized element variation patterns for low-K volcanic clasts from lithostratigraphic Units III and for evolved basaltic to andesitic sills from Unit $\mathrm{V}$ in Hole 833B.

geochemical study of Aoba lavas ( $<0.7 \mathrm{Ma}$; Eggins, 1993) showed the existence of two magmatic lineages on this island, an older high- $\mathrm{Ti}$ arc basalt suite $\left(1.1 \%-1.7 \% \mathrm{TiO}_{2}\right)$ and a younger, primitive low-Ti suite $\left(0.5 \%-1.1 \% \mathrm{TiO}_{2}\right)$. The low-Ti suite lavas span a continuous range from picrite $(20 \% \mathrm{MgO})$ to high- $\mathrm{Al}$ basalts $(<5 \% \mathrm{MgO})$, and can be related by crystal fractionation of observed phenocryst phases. 

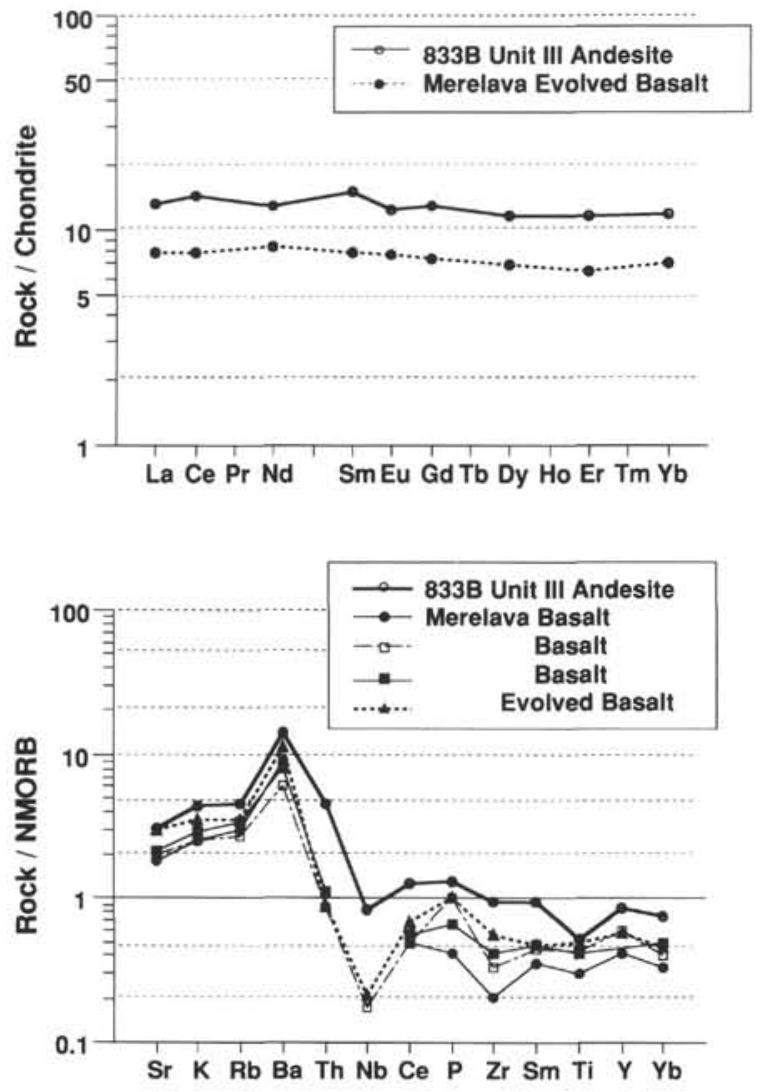

Figure 11. Top: Chondrite-normalized REE patterns for representative low-K andesitic clast from Hole 833B lithostratigraphic Unit III compared with representative andesitic lava from Merelava volcano (Barsdell, 1988) at the northeastern end of the North Aoba Basin. Bottom: NMORB-normalized element variation pattems for low-K clast from Hole 833B lithostratigraphic Unit III compared with patterns for representative andesitic and basaltic lavas from Merelava volcano (Barsdell, 1988) at the northeastern end of the North Aoba Basin.

Santa Maria volcano is a little-dissected low, truncated cone about 25 $\mathrm{km}$ across, with a central caldera. Dissected remnants of an older volcano suggest that it existed as a late Pliocene volcano (Mallick and Ash, 1975). The island is dominated by basalts and andesites, many of which have transitional alkaline, high-K characteristics (Barsdell et al., 1982).

Figures $12 \mathrm{~A}$ and $\mathrm{B}$ show representative REE and element variation patterns for the dominant low-Ti series, and the older, less-voluminous high-Ti series on Aoba (Eggins, 1993), and also a representative basalt from Santa Maria (Barsdell et al., 1982). The Aoba low-Ti series and high-Ti series lavas show essentially parallel element patterns between $\mathrm{Sr}$ and Th (Fig. 12B), and only vary for the HFSE elements. The Santa Maria lavas are clearly more akin to the low-Ti series on Aoba, lacking the pronounced enrichments in HFSE shown by the Aoba high-Ti series. Figures $12 \mathrm{~A}$ and $\mathrm{B}$ also show representative REE patterns and element variation diagrams for the compositional Group 1 and Group 2 basalts and andesites from Hole 832B lithostratigraphic Units VI and IV. The Aoba-Santa Maria lavas are compositionally akin to the Group 2 Hole 832B lavas, and lack the $\mathrm{Ba}-\mathrm{Rb}$ peak that characterizes the Group 1 lavas from Hole 832B. Both the high- $\mathrm{Ti}$ and low- $\mathrm{Ti}$ series represented on Aoba are also present among these Pliocene-Pleistocene lavas in Hole 832B, and there appears to be no temporal control on their occurrence in this hole, being represented in Units II, III, and IV. The high-Ti series lavas are not represented, however, among the few analyzed clasts from the Late Miocene Unit VI.
The Group 2 element variation pattern, with smoothly increasing curves from $\mathrm{Sr}$ to $\mathrm{Ba}$, occurs in Hole 832B lithostratigraphic Units III, IV, and VI, but is not represented on Aoba or Santa Maria. However, late Miocene lavas from Pentecost and Maewo, and also recent lavas from Ambrym and Epi volcanoes, further south in the arc, exhibit similar patterns (not shown).

The distinctive compositions of the evolved basaltic to andesitic sills in Hole 833B are compared with lavas of similar $\mathrm{MgO}$ content from the low- $\mathrm{Ti}$ and high-Ti series on Aoba in Figures $13 \mathrm{~A}$ and $\mathrm{B}$. The REE patterns of the sills, and their high HFSE contents indicate broad correlation with the high-Ti series on Aoba, although the sills are older by perhaps $3 \mathrm{~m}$.y. than the Aoba lavas. Slight differences are obvious in the $\mathrm{Sr}$ through Th sections of the element variation patterns (Fig. 13B) for the sills and the high-Ti Aoba andesites. However, given the significant age difference between the two magma series, and the distance between Site 833B and Aoba, this is not unexpected. The key point is that relatively HFSE-enriched basaltic magmas have been generated intermittently during the last $4 \mathrm{~m} . \mathrm{y}$. in the NAB region, but are volumetrically subordinate to the less HFSE-enriched series, best represented by the low-Ti series on Aoba (Eggins, 1993) and Santa Maria.

Preliminary trace element data for ashes from the upper sections of Holes $832 \mathrm{~B}$ and $833 \mathrm{~B}$ (Gérard and Person, this volume) suggest that the high-Ti series is not represented among the ashes, which presumably derive in large part from nearby Santa Maria volcano.

\section{CONCLUSIONS}

The stratigraphic occurrence and petrographical-geochemical features of the igneous rocks drilled from the NAB indicate the existence of the following four compositional groups:

1. Ankaramites or augite-phyric basalts and andesites of Pleistocene-Recent age, limited to Hole 832B lithostratigraphic Units II, III, IV, and VI. These are medium- to high-K compositions and are derived from a spectrum of parental magmas in which the HFSE contents are inversely proportional to their $\mathrm{SiO}_{2}$ contents. The latter feature may reflect derivation of this range of primary magmas from varying degrees of partial melting of an essentially similar source, possibly with the low-SiO $\mathrm{S}_{2}$, high-HFSE magmas representing lower degree partial melts generated by higher pressure partial melting.

2. Calc-alkaline two pyroxene-bearing basalts and andesites from the Middle Miocene lithostratigraphic Unit VII of Hole 832B. These are probably derived from the Western Belt, where calc-alkaline lavas are described but poorly documented. This assignment requires that the $5.66 \mathrm{Ma} \mathrm{K}$-Ar age for one sample from this suite is significantly too young, due to incipient alteration and Ar loss.

3. Ankaramites or olivine + augite-phyric low-K basalts and basaltic andesites of the Pleistocene-late Pliocene Unit III of Hole 833B. These have low HFSE contents and flat REE patterns and are correlated with the lavas of the Pleistocene to Holocene Merelava volcano, or a more proximal, compositionally-similar volcanic source in a similar tectonic setting to Merelava along the eastern margin of the NAB.

4. High-K basalt to shoshonitic augite + olivine-phyric evolved basaltic to andesitic sills of lithostratigraphic Unit V in Hole 833B; these are of Pliocene age, form a continuum of compositions related by fractional crystallization, and are compositionally correlated with the high-Ti K-rich basalts from Aoba volcano.

\section{ACKNOWLEDGMENTS}

The first author's participation on Leg 134 was financially supported by ODP Japan. Dr. A. Taira and Dr. K. Fujioka are especially thanked for providing this opportunity. Professor Ken'Ichiro Aoki, Dr. Y. Tatsumi, and Dr. K. Akimoto gave encouragement and support to the senior author. 

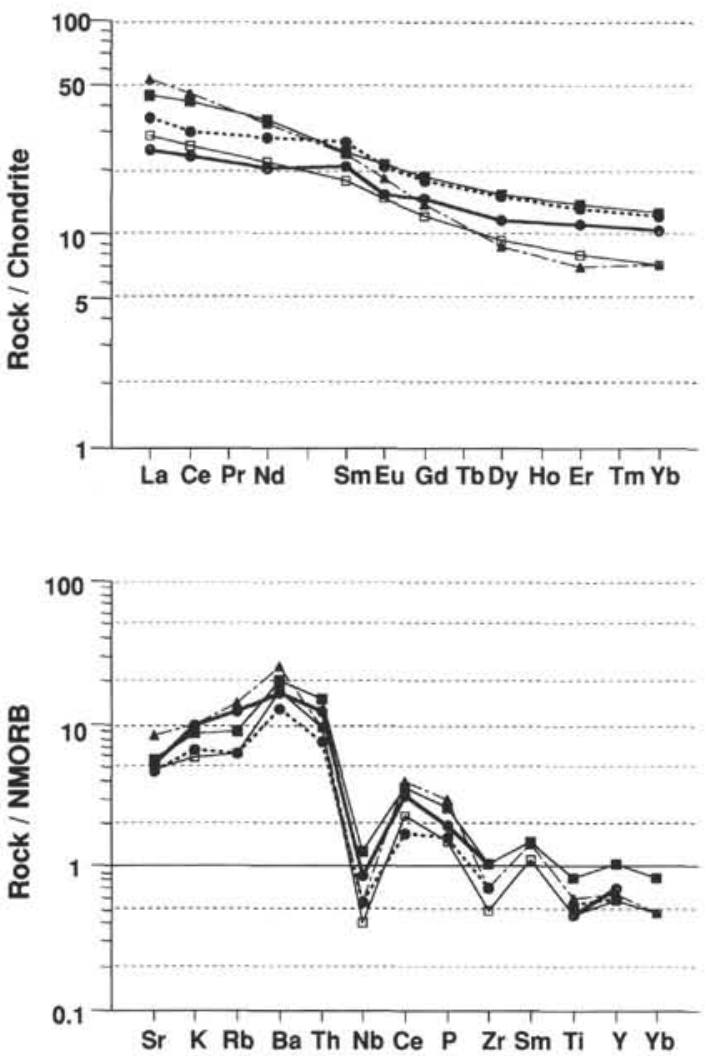

\begin{tabular}{|c|c|}
\hline & 832B Unit IV Basalt (REE) and \\
\hline . & 832B Unit IV Basalts (Group 2) \\
\hline$\rightarrow$ & Aoba Low-Ti Basalt \\
\hline$\because-$ & Aoba High-Ti Basalt \\
\hline$-\approx$ & Santa Maria Basalt \\
\hline
\end{tabular}

Figure 12. Chondrite-normalized REE patterns (top) and NMORB-normalized element variation patterns (bottom) for representative lavas from Hole 832B lithostratigraphic Units IV and VI compared with lavas from the high-Ti and low-Ti series of Aoba and a Santa Maria andesite. Data from Eggins (1993) and Barsdell et al. (1982).

\section{REFERENCES*}

Auzende, J.-M., Lafoy, Y., and Marsset, B., 1988. Recent geodynamic evolution of the North Fiji Basin (Southwest Pacific). Geology, 16:925-929.

Barsdell, M., 1988. Petrology and petrogenesis of clinopyroxene-rich tholeitic lavas, Merelava volcano, Vanuatu. J. Petrol., 29:927-964.

Barsdell, M., Smith, I.E.M., and Sporli, K.B., 1982. The origin of reversed geochemical zoning in the Northern New Hebrides Volcanic Arc. Contrib. Mineral. Petrol., 81:148-155.

Carney, J.N., 1986. Geology of Maewo. Region. Rep.-Vanuatu Dep. Geol., Mines and Rural Water Suppl.

Carney, J.N., and Macfarlane, A., 1982. Geological evidence bearing on the Miocene to Recent structural evolution of the New Hebrides Arc. Tectonophysics, 87:147-175.

Charvis, P., and Pelletier, B., 1989. The northern New Hebrides back-arc troughs: history and relation with the North Fiji basin. Tectonophysics, 170:259-277.

Chase, C.G., 1971. Tectonic history of the Fiji plateau. Geol. Soc. Am. Bull., 82:3087-3110.

Collot, J.-Y., Greene, H.G., Stokking, L.B., et al., 1992. Proc. ODP, Init. Repts., 134: College Station, TX (Ocean Drilling Program).

* Abbreviations for names of organizations and publications in ODP reference lists follow the style given in Chemical Abstracts Service Source Index (published by American Chemical Society).
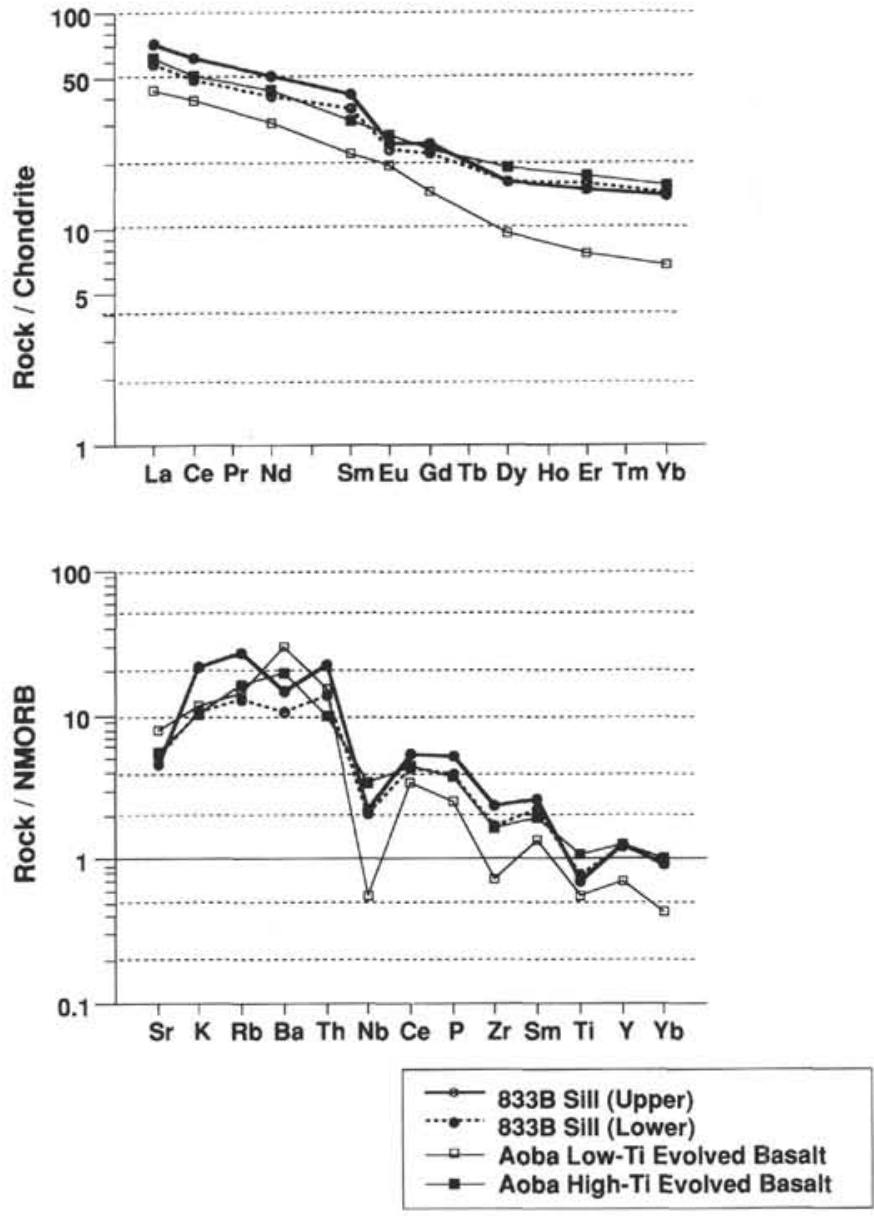

Figure 13. Chondrite-normalized REE patterns (top) and NMORB-normalized element variation patterns (bottom) for high-K evolved basaltic to andesitic sills from Hole 833B lithostratigraphic Unit V compared with two basaltic andesite lavas from Aoba. Data from Eggins (1993) and Barsdell et al. (1982).

Eggins, S.M., 1993. Origin and differentiation of picritic arc lavas from Aoba (Ambae), Vanuatu. Contrib. Mineral. Petrol., 114:79-100.

Falvey, D.A., 1978. Analysis of paleomagnetic data from the New Hebrides. Australas. Soc. Explor. Geophys. Bull., 9:117-123.

Fisher, M.A., Falvey, D.A., and Smith, G.L., 1988. Seismic stratigraphy of the summit basins of the New Hebrides island arc. In Greene, H.G., and Wong, F.L. (Eds.), Geology and Offshore Resources of Pacific Island ArcsVanuatu Region. Circum-Pac. Counc. Energy Miner. Resour., Earth Sci. Ser., 8:201-223.

Gill, J.B., 1981. Orogenic Andesites and Plate Tectonics: New York (SpringerVerlag).

Gorton, M.P., 1974. The geochemistry and geochronology of the New Hebrides [Ph.D. dissert.]. Australian National Univ., Canberra.

1977. The geochemistry and origin of Quaternary volcanism in the New Hebrides. Geochim. Cosmochim. Acta, 41:1257-1270.

Greene, H.G., Macfarlane, A., and Wong, F.L., 1988. Geology and offshore resources of Vanuatu-introduction and summary. In Greene, H.G., and Wong, F.L. (Eds.), Geology and Offshore Resources of Pacific Island Arcs-Vanuatu Region. Circum-Pac. Counc. Energy Miner. Resour., Earth Sci. Ser., 8:1-25.

Hamburger, M.W., and Isacks, B.L., 1987. Deep earthquakes in the Southwest Pacific: a tectonic interpretation. J. Geophys. Res., 92:13841-13854.

Holmes, M.L., 1988. Seismic refraction measurements in the summit basins of the New Hebrides Arc. In Greene, H.G., and Wong, F.L. (Eds.), Geology and Offshore Resources of Pacific Island Arcs-Vanuatu Region. CircumPac. Counc. Energy Miner. Resour., Earth Sci. Ser., 8:163-176.

Johnson, D.P., Belford, D.J., Carter, A.N., and Crawford, A.J., 1988. Petrology and age of dredge samples collected in the Central Basin, Vanuatu. In Greene, H.G., and Wong, F.L. (Eds.), Geology and Offshore Resources of 
Pacific Island Arcs-Vanuatu Region. Circum-Pac. Counc. Energy Miner. Resour., Earth Sci. Ser., 8:141-162.

Karig, D.E., and Mammerickx, J., 1972. Tectonic framework of the New Hebrides island arc. Mar. Geol., 12:187-205.

Macfarlane, A., Carney, J.N., Crawford, A.J., and Greene, H.G., 1988. Vanuatua review of the onshore geology. In Greene, H.G., and Wong, F.L. (Eds.), Geology and Offshore Resources of Pacific Island Arcs-Vanuatu Region. Circum-Pac. Counc. Energy Miner. Resour., Earth Sci. Ser., 8:45-91.

Mallick, D.I.J., and Ash, R.P., 1975. Geology of the Southern Banks Islands. Reg. Rep.-New Hebrides Geol. Surv.

Miyashiro, A., 1974. Volcanic rock series in island ares and active continental margins. Am. J. Sci., 274:321-355.

Nakamura, N., 1974. Determination of REE, Ba, Fe, Mg, Na, and $\mathrm{K}$ in carbonaceous and ordinary chondrites. Geochim. Cosmochim. Acta, 38:757-776.
Pascal, G., Isacks, B.L., Barazangi, M., and Dubois, J., 1978. Precise relocations of earthquakes, and seismotectonics of the New Hebrides island arc. J. Geophys. Res., 83:4957-4973.

Pearce, J.A., 1983. The role of sub-continental lithosphere in magma genesis at active continental margins. In Hawkesworth, C.J., and Norry, M.J. (Eds.), Continental Basalts and Mantle Xenoliths: Nantwich (Shiva Publ.), 230-249.

Date of initial receipt: 23 March 1993

Date of acceptance: 24 September 1993

Ms 134SR-018 